\title{
Why the United States Led in Education: Lessons from Secondary School Expansion, 1910 to 1940
}

\section{Citation}

Goldin, Claudia, and Lawrence F. Katz. 2009. "Why the United States Led in Education: Lessons from Secondary School Expansion, 1910 to 1940." In Human Capital and Institutions: A Long-Run View, eds. D. Eltis, F. Lewis, K. Sokoloff. Cambridge: Cambridge University Press.

\section{Published Version}

http://www.cambridge.org/us/academic/subjects/history/history-after-1945-general/humancapital-and-institutions-long-run-view?format=HB\&isbn=9780521769587\#fJFIEclbpAcAF9p0.97

\section{Permanent link}

http://nrs.harvard.edu/urn-3:HUL.InstRepos:32785053

\section{Terms of Use}

This article was downloaded from Harvard University's DASH repository, and is made available under the terms and conditions applicable to Open Access Policy Articles, as set forth at http:// nrs.harvard.edu/urn-3:HUL.InstRepos:dash.current.terms-of-use\#OAP

\section{Share Your Story}

The Harvard community has made this article openly available.

Please share how this access benefits you. Submit a story.

\section{Accessibility}


NBER WORKING PAPER SERIES

\author{
WHY THE UNITED STATES LED IN \\ EDUCATION: LESSONS FROM SECONDARY \\ SCHOOL EXPANSION, 1910 TO 1940
}

Claudia Goldin

Lawrence F. Katz

Working Paper 6144
http://www.nber.org/papers/w6144

NATIONAL BUREAU OF ECONOMIC RESEARCH
1050 Massachusetts Avenue
Cambridge, MA 02138
August 1997

We gratefully acknowledge research support from the Spencer Foundation and from the National Science Foundation through the National Bureau of Economic Research. We thank Mireille Jacobson and David Sherwood for providing fine research assistance on the cross-country portion of the project. The state- and city-level data on secondary schools were collected when Claudia Goldin was on leave at the Brookings Institution during 1993/94, and she thanks Linda Tuch for research assistance at Brookings and Maya Federman for the same at Harvard University. Seminar participants at University of Texas, Austin, Harvard University Labor Workshop, Society of Labor Economists meetings, the University of California at Davis, and the NBER-DAE Summer Institute provided helpful suggestions. Special thanks to Caroline Hoxby, William Johnson, Peter Lindert, and Andrei Shleifer for comments; to Carl-Ludwig Holtfrerich for decoding the German educational system for us; to Stefanie Schmidt for help with state compulsory education laws; and to Robert Whaples for 1910 and 1920 city data. This paper is part of NBER's research programs in the Development of the American Economy and Labor Studies. Any opinions expressed are those of the authors and not those of the National Bureau of Economic Research.

(C) 1997 by Claudia Goldin and Lawrence F. Katz. All rights reserved. Short sections of text, not to exceed two paragraphs, may be quoted without explicit permission provided that full credit, including $(\mathbb{C}$ notice, is given to the source. 
Why the United States Led in Education: Lessons

from Secondary School Expansion, 1910 to 1940

Claudia Goldin and Lawrence F. Katz

NBER Working Paper No. 6144

August 1997

JEL Nos. H4, I2, N3

Development of the American Economy

and Labor Studies

\section{ABSTRACT}

The "second transformation" of U.S. education — the growth of secondary schooling occurred swiftly in the early 1900s and placed the educational attainment of Americans far ahead of that in other nations for much of the twentieth century. Just 9 percent of U.S. youths had high school diplomas in 1910, but more than 50 percent did by 1940. By the mid-1950s the United States was 35 years in front of the United Kingdom in the educational attainment of 14 to 17-year olds. What can explain why secondary schooling advanced in the United States, why differences in secondary schooling emerged across U.S. states and cities, and why America led the world in educational attainment for much of the twentieth century? Although we motivate the paper with international comparisons, the core of the analysis exploits the considerable cross-state, cross-city, and time-series variation within the United States.

The areas of the United States that led in secondary school education (the Far West, Great Plains, and parts of New England) were rich in income and wealth, had high proportions of the elderly, and had relative equality of wealth or income. Given wealth, they also contained a low proportion of jobs in manufacturing and low percentages immigrant and Catholic. Homogeneity of economic and social conditions, and the social stability of community, given a modicum of income or wealth, also fostered the extension of education to the secondary school level.

Claudia Goldin

Department of Economics

Harvard University

Cambridge, MA 02138

and NBER

goldin@nber.org
Lawrence F. Katz

Department of Economics

Harvard University

Cambridge, MA 02138

and NBER

katz@nber.org 
In the first several decades of this century, the United States pulled far ahead of all other countries in the education of its youth. It underwent what was then and now termed the "high school movement," a feat most other western nations would accomplish thirty years later, if not more. The accomplishment, moreover, was achieved under a highly decentralized system of education. Most industrialized nations outside North America had, and continue to have, more centralized educational systems. The United States, on the other hand, contained 48 states and about 125,000 oftenindependent school districts during the period of the high-school movement.

This paper addresses how the "second transformation" of American education, as it is known, occurred and why America led the world in education for much of the twentieth century. ${ }^{1}$ We confront these issues by looking across the United States at the state and city levels. Cross-national schooling data are non-comparable for much of the period we explore. Although we motivate the paper with international comparisons, the core of our analysis exploits the considerable cross-state, cross-city, and time-series variation within the United States. The United States was a sufficiently heterogeneous country that many cross-national differences in income, wealth, inequality, the age structure, manufacturing, and religion can be duplicated across its states and cities.

In the three decades from 1910 to 1940 , America underwent a spectacular educational transformation. Just 9 percent of its youths had high school diplomas in 1910, but more than 50 percent did by 1940 (see Figure 1). As swift as the transformation was for the nation as a whole, it was considerably more rapid in many non-southern states and cities. Secondary-school enrollment and graduation rates, in most northern and western states, increased so rapidly that by the mid-1930s they were as high as they would be in 1960. The high-school movement in the United States was unique

\footnotetext{
'The first transformation was the achievement of widespread public primary-education, which was accomplished in the mid-nineteenth century. The third transformation, still in motion, is the rise of higher education which swiftly increased after World War II. By "education" we mean years of formal schooling rather than the content of schooling and training.
} 
for its time and set the United States far apart from virtually all nations in its human capital stock. ${ }^{2}$

Earlier in its history, the United States had also taken a commanding position in education. During the mid-nineteenth century, America surpassed the high enrollment levels achieved in Germany and took the lead in primary (grammar, elementary, or common) school education (Easterlin 1981). But by the turn of the twentieth century, various European countries had narrowed their educational gap with the United States. As the high school movement took root in America, however, the educational gap reappeared and then enlarged considerably to mid-century. Educational differences between youths in the United States and those in many European countries would not again be reduced for some time, and in many cases only recently. 'The relative stock of educated workers, therefore, was considerably greater in America in the 1950 s and 1960 s than it was in most European countries. ${ }^{3}$

The areas of the United States that led in secondary school education, we will show, were rich in income and wealth, had high (not low) proportions of the elderly, and had relative equality of wealth or income. Given wealth, they also contained a low proportion of jobs in manufacturing and low percentages immigrant and Catholic. Homogeneity of economic and social condition, and the social stability of community, given a modicum of income or wealth, also fostered the extension of education to the secondary school level.

Some of the explanatory variables of significance come from a simple model of educational investment. Where the opportunity cost of schooling was high and family income or wealth was low, education, not surprisingly, lagged. Other variables originate in a framework of public, not individual, choice. The extension of education to the secondary level required schools to be built and teachers to

\footnotetext{
${ }^{2}$ Canada underwent a similar, but slower, increase in secondary schools at the same time. See Urquhart and Buckley 1965.

${ }^{3}$ This point does not necessarily follow from the previous statements on educational flow since the educational stock (meaning average years of school) of Americans was diluted by immigration. But because the level of education of the nativebom population was so high, compared with that in Great Britain, for example, the dilution effect does not overtum the claim.
} 
be hired. The decision was not whether or not a family would send a child to school. Rather the choice was whether a school district, township, county, or state would tax everyone to educate other peoples' children. Areas with greater homogeneity of economic condition, higher levels of wealth, and more community stability were the earliest to expand education to the secondary level and had the greatest expansion during the initial years of the high school movement. Also of importance was the state's prior commitment to publicly-funded colleges, which increased the return to high school.

The differences between the United States and European countries in secondary schooling may be linked to the variables we find of importance in the cross-section study, particularly the distribution of income and wealth. But there are other differences that are harder to model and quantify. In most European countries educational finance and decision-making was far more centralized than it was in the United States. Most public choice models do not offer unambiguous guidance concerning whether the voting equilibrium in the centralized or decentralized system generates the outcome closest to the Pareto Optimal one (see, e.g., Hoxby 1996). We believe that the parameters of the early to midtwentieth century experience operated to increase public school resources in areas with the least centralized systems, although that need not always be the case.

We begin with a brief description of the high-school movement in the United States and an equally brief discussion of international differences in education during the period under consideration. We then address the central questions of the paper: What can explain differences in secondary schooling across U.S. states and cities in each of several periods, and what can explain the rapid rise of secondary education through time? The implications of these differences for economic growth are then explored. We conclude by returning to the international differences. 


\section{THE HIGH SCHOOL MOVEMENT IN THE UNITED STATES: 1910 TO 1940}

By the first decade of the twentieth century the vast majority of American youth outside the South attended school until they were 14-years old, and those in the northern and western states, as in some European countries, had attained nearly universal "common schooling" of at least six years. America was poised for a transition from the elementary and common schools to the secondary level. ${ }^{4}$

Across much of America, starting perhaps in the 1890 s, the demand for educated workers to staff ordinary white-collar jobs began to soar. People in even rural areas spoke of having a high-school education as a means of succeeding in the business community, and parents across diverse communities saw secondary education as the premier ticket to their children's prosperity. By the 1910s a clamor was heard for the extension of high schools to the "open country" of America. ${ }^{5}$ But success in much of America meant more than economic mobility. It also required geographic mobility, for America was still largely a rural land. Education also encouraged and enabled migration out of rural America.

We have shown, elsewhere, that the premium to ordinary white-collar employment in the immediate pre-World War I period was high and that it probably rose throughout the latter part of the nineteenth century (Goldin and Katz 1995; Goldin and Katz 1997; Goldin 1997). The ratio of the earnings of men in clerical and managerial positions $\left(w_{c}\right)$ to those of male production workers in manufacturing ( $\mathrm{w}_{\mathrm{p}}$ ) was 2.372 in 1914 . Because, at that time, most beginning clerical positions required

\footnotetext{
${ }^{4}$ Of all native-born, white men 40 to 49 years old in 1940, 27 percent had not completed eighth grade, and of those born outside the South 19 percent had not. Just 7 percent of this latter group had not completed 6 years. Those who were 40 to 49 years old in 1940 would have been 14 from 1905 to 1914 . Source: 1940 PUMS $1 / 100$ sample.

${ }^{5}$ Word War I did much to solidify these notions. According to the Iowa Commissioner of Education, "Those who have a high school education have risen in mank [during World War $I$ ]... The business world is also more and more demanding young men and women of high school training" (Iowa Department of Public Instruction 1916-1918, p. 45). Most of the reports of educational commissioners in the more progressive states speak to this point, but these documents might be considered suspect since state bureaucracies had interests in propagandizing. The aspirations of ordinary Americans can be gleancd from the literature of the day. Theodore Dreiser, O.Henry, Sinclair Lewis, Sherwood Anderson, Willa Cather, and John Dos Passos all emphasized the high-school educated and what education meant in their lives. In Dreiser, O.Henry, Lewis, Cather, and Anderson a high-school education meant the ability to leave rural America. For all these writers high-school was associated with respectability and success. It also meant potential independence for women.
} 
some high school, if not a diploma, and production workers in manufacturing generally did not have high school training, the ratio indicates a substantial return to high school education. ${ }^{6}$ But the relative wage of clerical workers would decline soon after the blossoming of the high school movement.

Before 1900, although American secondary schools existed in almost all large cities and in many smaller towns, they were not standardized and often had close connections with local universities or colleges, training students to pass their entrance exams. Almost half the high school graduates in 1910 claimed they would continue their studies in college, university, or another form of higher education (e.g., in normal, library, and nursing schools). The fraction that actually entered a degree-granting institution was probably around 40 percent. Both percentages declined considerably by the mid-1930s, as high school enrollments soared (see Goldin 1997, table 2). ${ }^{7}$ The modern high school that we now know - with its diverse curriculum, vocational courses, tracking, electives, 45-minute periods, Carnegie units - was literally invented in America during the first decades of the twentieth century (see Krug 1964, 1972). The junior high school also originated in this era — in 1909 to be precise — as a device to give a diploma and vocational skills to the 14 -year old drop-out. ${ }^{8}$ Americans devised the secondary school for the masses that trained "for life," not just "for college."

Economists and historians have known for some time that the high school expanded nationally

\footnotetext{
${ }^{6}$ Direct evidence from individual-level data on earnings and education from the Iowa State Census of 1915 yields a return to a year of high school in three of Iowa's largest cities of 11 percent for males and 10 percent for females. These estimates are from log annual earnings regressions that include, among other variables, a quartic in potential experience, foreign-born status and years in the United States, and city effects. Note that the returns do not include the potentially large effect of migration from rural areas. See Goldin and Katz (1997).

${ }^{7}$ The 40 percent figure comes from taking the 1910 graduation total $(156,000$ including public and private) and dividing it by the number of entrants to degree-granting institutions of higher leaming, which we estimate to be 60,975 . There were 174,213 students in collegiate programs, (exchuding graduate and professional students but probably including those in teachers' colleges). We assume that 35 percent were in their first year. See U.S. Department of Education, Biennials 1928-1930, p. 338.

${ }^{8}$ The first junior high schools appeared in 1909 in two college towns: Berkeley, CA and Columbus, OH. By 192347 percent of cities $(>10,000$ population in 1910) outside the South had at least one junior high school and 70 percent did by 1927 (based on data from U.S. Bureau of Education, Biennials various years).
} 
in the 1910 to 1940 period. The data on high school enrollment and graduation rates, from contemporaneous sources and given in Figure 1, have been reproduced in various government publications (e.g., U.S. Bureau of the Census 1975; U.S. Department of Education 1993). Figure 1 clearly shows the extraordinary rise in secondary schooling for the entire United States, but does not reveal whether its diverse regions went through the educational transformation at the same time. The 1940 U.S. population census, the first to collect information on educational attainment, could be used to address the issue, but its schooling data for older cohorts are suspect. ${ }^{9}$

To produce state figures and to check the reliability of the national series we have used, instead, the contemporaneous reports of state and federal departments of education to construct the number of students entolled and graduated. The data were assembled as part of a study of education in the twentieth century (Goldin 1994, 1997).

The schooling data include all students in grades nine through twelve in public and private secondary schools, as well as those in the preparatory departments of colleges and universities. ${ }^{10}$ For the state-level data we have two measures: enrollment and graduation. ${ }^{11}$ They are each transformed

\footnotetext{
${ }^{9}$ For evidence concerning why the 1940 federal population census contains suspect data overstating the educational attainment of older cohorts, see Goldin (1997). Only two states, prior to 1940, had censuses that inquired of educational attainment (Iowa in 1915 and 1925; South Dakota in 1915). Various U.S. federal population censuses inquired as to the attendance of individuals in school at any time during the preceding year. We use these data in the city-level analysis, but the state-wide levels for this variable do not appear reasonable especially for the South.

${ }^{10}$ The data include those in 2-, 3-, or 4-year public and private high schools, in the final year of junior high, and in the preparatory departments of colleges and universities. They do not generally include students attending common schools beyond eight years in place of formal high schools, although in some states they probably do. Students in the preparatory departments of colleges and universities have been omitted from all other series we know of despite the fact that they accounted for about one-third of all private-school students in the 1910s.

${ }^{11}$ There are no attendance numbers, conveniently located, for all states and all years in our sample. For the states we have been able to find, the average daily attendance is generally more than 80 percent of enrollment. We have average daily attendance data in the city-level sample, to be presented below. There is no apparent reason for an overstatement of enrollment since the states provided little to localities on the basis of student numbers. Graduation numbers, however, are generally cleaner in the sense that the concept is less ambiguous than is enrollment. States, then as today, set their own requirements for graduation which involved fulfilling various course and credit requirements in an accredited high school and, at times, passing a state-wide examination.
} 
into rates by dividing by the relevant demographic group. ${ }^{12}$ To conserve on space, we graphically present the information on graduation only; the trends and regional differences in enrollment are similar. We first summarize considerable information by presenting time-series of the graduation rates aggregated by census divisions and, then, three years of data in map form by states.

As can be seen in Figure 2, the increase in graduation rates was so steep that even before 1930 the states in many of the northern and western regions had achieved rates equal to those of the 1950s. It should be evident that the national data in Figure 1 give the misleading impression that the initial increase continued in most regions into the 1950s. Because the South lagged behind the North, the data for the entire country suggest a more continual increase.

But even outside the South there were laggards. The states with the lowest graduation rates in Figure 2 are most of the industrial areas of the country, particularly the states of the Mid-Atlantic. With the onset of the Great Depression, and with the N.I.R.A. codes (1933 to 1935) that made youthful employment in manufacturing illegal, teenagers in the industrial states flocked to high school, closing wide educational differentials among the states outside the South.

The South, as can be seen in Figure 3, had rates that were the lowest to begin with and which increased more slowly at first. The growth continued beyond the 1930 s, and by the 1950 s the states of the South caught up to those in the East North Central, included in Figure 3 for comparison. The low graduation rates in the South before 1950, moreover, were not simply due to the low levels for the African-American population. The white population also had far lower rates than in the rest of the United States, as can be seen by the line drawn for whites in the South Atlantic.

Several other items in the underlying data should also be mentioned. Although the data for the states begin, by necessity, with 1910, estimates for the entire nation reveal that change was slow for the

\footnotetext{
${ }^{12}$ We divide by 17 -year olds for the graduation rate, and by those 14 to 17 -years old for the enrollment rate.
} 
four previous decades. That is, the 1910 level is not much higher than it was in $1870 .{ }^{13}$ The 1910 to 1940 segment in Figure 2, therefore, can be thought of as the rapidly rising portion of a logistical function. ${ }^{14}$ Another point is that World War II cut into the high school graduation (and the enrollment) numbers not because of the draft but, rather, because of the relatively high wages for workers with little job experience. ${ }^{15}$ Finally are gender differences, not revealed in these graphs. Throughout America, from 1910 to 1940 , young women went to and graduated from secondary school at a higher rate than did young men, with the possible exception of the 1930 s when they were on par.

Geographical differences in graduation rates at three dates - 1910 1928, and 1938, those that will be used for the regressions - are given in the maps of Figure 4. At the start of the high-school movement, New England was in the forefront, as it had been during the nineteenth century in elementary education. Several states in the mid-section of the country also had extremely high schooling rates and afford a glimpse of things to come. By $1928 \mathrm{New}$ England was eclipsed by these states and by others spread clear across the northern and western parts of America. The group forms an "educational belt" across America. Enrollment and graduation rates in California, Oregon, Washington, Nebraska, Kansas, Iowa, Indiana, a host of the less-populous mountain states, and part of New England were far higher than they were in New York, New Jersey, Pennsylvania, Michigan, Wisconsin, and, of course, throughout the South. ${ }^{16}$ Although there was considerable catch-up by 1938 between the leaders and the more industrial states just mentioned, the ranking of the states is similar, as can be seen by comparing the maps for 1928 and 1938 .

\footnotetext{
${ }^{13}$ See U.S. Department of Education (1993, table 19).

${ }^{14}$ It is a logistical function, however, that later rises again. High school graduation rates increased once more after 1960.

${ }^{15}$ One indication that many high school males left school to take the relatively well-paying unskilled jobs of war-time is that young women did as well, particularly in the regions with the greatest fraction of war industries.

${ }^{16}$ We present only the graduation statistics in the maps.
} 
Comparisons over time are facilitated by consulting Table 1, which gives the mean, standard deviation, and coefficient of variation of high school graduation rates by state (weighted and unweighted), for selected years from 1910 to 1938 . Interestingly, the two dispersion measures yield different results. Although both the unweighted and weighted standard deviations of state graduation rates suggest widening dispersion, the coefficient of variation for the 48 states, in contrast, reveals convergence. Because the log income is approximately linear in years of schooling, according to substantial evidence, the standard deviation of education in years (here proxied by the standard deviation in high school graduation rates) is a sensible proxy for the standard deviation in (log) permanent income. It is, therefore, as well a reasonable measure for the impact of education on income inequality. Thus, Table 1, by our interpretation, reveals growing gaps in high school education across the nation during the period of the high school movement. Within the non-South, however, the Great Depression produced a narrowing in high school graduation rates (see weighted results), as the industrial states of the North narrowed the gap between them and the states of the West and Plains.

The spread of high school education in America was a remarkable transition. It occurred in a brief period of time. By 1940 it was, except for the South, universal in its geographic coverage. Most estimates show that the direct cost of educating a high-school student was twice that of an elementaryschool pupil (Goldin 1997). Thus an area moving from universal elementary schooling (8 years) to universal secondary schooling (12 years) would double the size of its tax bill devoted to education. Even though high school was relatively expensive education, it increased rapidly. Moreover, the areas to which the high school spread most rapidly were among the more sparsely settled. In 1925 the average farm in Iowa had 160 acres and that in Nebraska, 330 acres (U.S. Department of Commerce 1926). Although Iowa and Nebraska were farm-country, they were also two of the leading states in secondary-school education. Given that 50 percent of Americans were still living in rural areas in 1920 , 
the timing of the high-school movement is not surprising given the obvious importance of the internal combustion engine (school buses, cars) and improved roads.

The modem U.S. high school was a quintessential American innovation: generally free, open to all who completed eighth grade, and, in most states, a guarantor of admission to a publicly-funded college for its graduates. No where else in the world was that the case when the U.S. high school movement was in its early stages. ${ }^{17}$

\section{INTERNATIONAL COMPARISONS}

The same pressures that mounted in the New World and led to an expansion of secondary education, were present across the Atlantic (Phelps Brown 1977). But they found expression in educational advance considerably later. When, during World War II, President Roosevelt formulated the GI Bill of Rights to fund college for millions of Americans, his counterpart in Great Britain, Prime Minister Churchill, was given a bill that granted youth the right to free secondary-school education. ${ }^{18}$

Making cross-country, cross-time comparisons in schooling is not a simple matter. The data differ by whether the information concerns enrollment or attendance, and whether it refers to publicschool students or to all. And there is the more vexing problem of defining schooling levels. In the United States, for example, secondary school has historically been defined as beginning with grade 9 and ending with grade 12, and youths attending such grades are generally between 14 and 18 -years old. But in England and Wales, secondary school begins at age 11.5, and in Germany it begins at age 10.

\footnotetext{
${ }^{17}$ As noted above, the Canadian experience is vaguely similar to that of the United States. Thus, it was North America, not just the United States that was truly distinctive. Canadian enrollment (public and private) data by province are similar to, though far lower than, those in the states just south of the border. In 1941, for example, the 14 to 17 -year old enrollment rate for Ontario was 40.3 percent; that for the Mid-Atlantic was 83.6 percent. The rate for British Columbia was 55.3, whereas for the Pacific states it was $\mathbf{9 2 . 0}$ percent. The Maritimes and Quebec look more like the American South in this comparison. See Urquhart and Buckley (1965).

${ }^{18}$ On the GI Bill, see Olson (1974). It should be noted that the GI Bill funded education of all types and only one-quarter of the recipients used their funding for college education.
} 
Thus the school level or grade would be a misleading unifier. A related complication is that secondary schooling can be an extension of primary education that would ordinarily stop at the equivalent of grade 8 . The use of primary schools as institutions of secondary education was more frequent in countries (and states) that did not yet have universal publicly-funded high schools. ${ }^{19}$ Thus the most reasonable comparison is for a particular age group, not by schooling level. ${ }^{20}$

In the several European countries for which we can make comparisons with the United States, we find that enrollment rates for youth 5 to 19-years old had already begun to catch up to those in the United States by the late-nineteenth century and that by the early-twentieth century they were quite close. For example, the ratio of the 5 to 19 -year old enrollment rate in France to that in the United States was 0.93 in 1911. In the same year, it was 0.96 in Germany and 0.82 in the United Kingdom. But by $1925 / 26$ the ratios had slid to 0.70 for France, 0.78 for Germany, and 0.77 for the United Kingdom. ${ }^{21}$ Thus, the high-school movement in the United States set it apart from other industrialized economies in Europe in terms of educational attainment.

The data just presented include students at all levels of education and do not make the

\footnotetext{
${ }^{19}$ In England and Wales, for example, youths in the pre-1944 period who did not qualify for the limited number of tuitionfree positions at private schools receiving some state funds, often extended their years in school by attending primary school in to their teens. In certain parts of rural America the same was true during the initial phase of the high school movement.

${ }^{20}$ These and other problems may be behind the data offered in Maddison (1987, table A-12; see also Matthews, Feinstein, and Odling-Smee 1982, p. 573), and cited in Nelson and Wright (1992). Maddison presents numbers indicating that the educational stock of the U.K. population exceeded that of the United States early in the century and that, moreover, the number of secondary-school years per person in the United Kingdom exceeded that in the United States in 1913. Maddison states, as well, that in 1950 the U.K. population 15 to 64 -years old had 3.27 years secondary school, on average, and that the figure for the United States was 3.40. But only about 14 percent of British 15 to 18-year olds were in school in 1950, whereas the United States was graduating 59 percent of its youth from high schools and 75 percent were enrolled in high schools. In addition, the U.S. advantage in education goes back for decades (see Table 2). One possible difference in the two countries is the number of foreign born in the United States. But the proportion of less-educated foreign-born in the U.S. population cannot make up the difference.

21 The European data are from Mitchell (1992) for enrollment or attendance and population. The U.S. data are from U.S. Bureau of the Census (1975). As noted above, educational data are often treacherous and some of the data in Mitchell appear highly suspect. For example, there were many post-World War I educational reforms in France, yet the enrollment rate for 5 to 19-year olds declines in the mid-1920s. The enrollment rate for 5 to 19 -year olds in Germany in 1933/35 exceeds 100 percent. We do not believe, however, that these problems affect our conclusion with regard to catch-up to the United States followed by divengence.
} 
adjustments we argued for above. We can offer more meaningful comparisons for the age groups of interest by contrasting the United States with England and Wales (and, at times, Great Britain). ${ }^{22}$ In 1913, at the start of the period we are studying, per capita income in Great Britain was 83 percent of that in the United States and just twenty years before the two were approximately equal. Per capita income in France and Germany was about 55 percent of the U.S. figure in $1913 .^{23}$ Thus, the comparison of educational levels in the United States with those in Great Britain appears to make most sense in terms of two countries with approximately equal income per capita at the start of the period.

The data we have assembled for the two countries include all students (public and private) in the age group believed to encompass the secondary-school years in the United States. Table 2 gives attendance rates in Great Britain for youth at those ages and the high-school enrollment (and graduation) rates in the United States. Attendance as defined in Great Britain, it should be noted, may be more like enrollment as defined in the United States, but, to be conservative, we will assume that average daily attendance was meant. The difference between the two countries in the schooling rate for the 14 to 17 -year old group, using our assumptions, grew from 4 percentage points in 1910, to 37 percentage points in 1938 , before narrowing, a bit, to 31 percentage points in $1956 .{ }^{24}$ By the end of the high-school movement in the United States, the educational attainment of its youth vastly exceeded

\footnotetext{
${ }^{2}$ Because these data are difficult to construct, we have produced them only for England and Wales (and, at times, Great Britain). We had to estimate the number of youths in private or partially-subsidized secondary schools, those in extended programs in elementary schools, and the age of students rather than type of school or grade.

${ }^{23}$ All figures are from Maddison (1991) and are expressed in constant purchasing-power-parity terms.

${ }^{24}$ The attendance rate data for 14 to 17 -year olds in Great Britain $(8$ percent in $1911 ; 21$ percent in 1938 ; and 40 percent in 1956) are calculated as follows. We use an approximate relationship among the attendance rates across the various ages from 14 to 17-years and estimate the mean given the limited information in Table 2 . We then multiply the U.S. data by 0.85 , to get the approximate attendance rate from the enrollment rate numbers, and subtract. The computation, most likely, understate the difference at all dates because attendance in England/Wales meant "on the registers" which may be closer to enrollment than to average daily attendance. If the data for Great Britain are actually enrollment numbers, then the differences with the United States are: 6, 47, and 43 percentage points. The differences may be even more understated in 1911 because the actual 14 to 17-year old enrollment rate in the United States was probably higher than the enrollment rate of youths in secondary schools. Some 14 to 17 -year olds were in extended common school education and some were in the lower grades.
} 
that in Great Britain. ${ }^{25}$ By 1956 Great Britain was 35 years behind the United States in the educational attainment of its high-school aged youth even though it had a fully supported public secondary school system since $1944 .^{26}$

\section{EXPLAINING DIFFERENCES IN HIGH-SCHOOL PARTICIPATION RATES ACROSS THE UNITED STATES}

To understand the wide differences in high school attendance and graduation rates across the American states and the reasons why the United States led all nations in education, we investigate the determinants of secondary school rates at the beginning of their steep ascent. For the state-level data we analyze, first, graduation rates at the dawn of the high-school movement in 1910 . We then traverse the initial surge in high-school enrollment and graduation rates by exploring the transformation in education from 1910 to 1928 . Next we explore the changes from the eve of the Great Depression to just before World War II, from 1928 to 1938 . A city-level data set affords a wider range of variables but requires the use of a different measure of the schooling rate. The motivation for all the estimations is a standard model of human capital investment in which the educational return, opportunity cost, and capital constraints affect private decisions. Layered on that model is a public-choice framework.

The simplest form of the investment decision is a two-period model in which a representative individual can either work or attend school in period 1 . If he works he earns $w_{1}$, whereas attending

\footnotetext{
${ }^{25}$ Although we have not compiled similar data for Germany, Ringer's (1979) evidence reveals that the 1931 figure for 15 to 18-year olds was 10 percent, identical to that for Great Britain. But Germany had, in addition, far more students in part-time technical institutions than did either the United States or the United Kingdom

${ }^{2}$ Many European countries funded technical education for high-school aged youths. The inclusion of those in full-time technical schools, particularly with an academic component, might be justified. Cross-country data for both full-time and parttime technical training exists for the mid-1950s. The inclusion of youths in full-time technical schools about doubles rates in the Scandinavian countries (Finland, Iceland, Norway, Sweden), as well as in Belgium, Denmark, France, Luxemburg, and the Netherlands. For example, the rate increases from about 15 percent to 30 percent in Norway. But even then, they are only half the level of the U.S. secondary-schooling rate, which was about 60 percent for 15 to 19 -year olds. Including part-time technical training greatly increases rates in these countries as well as in Germany and the United Kingdom, although there is less justification for including such students in the secondary schooling numbers. See Dewhurst et al. (1961).
} 
school, the alternative, entails a direct cost of $C$ and an opportunity cost of $\mathrm{w}_{1}$. The individual in period 2 earns $\mathrm{w}_{2}\left(2 \mathrm{w}_{1}\right)$ with no high school and $\mathrm{E}_{2}\left(>\mathrm{w}_{2}\right)$ with high school. The decision to attend school, under lifetime income maximization and given discount rate $r$, hinges on whether:

$$
\frac{\frac{E_{2}}{w_{2}}-1}{1+r}>\frac{C+w_{1}}{w_{2}}
$$

or expressed in terms of the rate of return calculation:

$$
\frac{E_{2}-w_{2}}{C+w_{1}}-1>r
$$

Thus the schooling decision is negatively related to the opportunity cost of schooling $\left(w_{1}\right)$, its direct $\operatorname{cost}(\mathrm{C})$, and the discount rate $(\mathrm{r})$, and positively affected by the high school wage premium $\left(\mathrm{E}_{2} / \mathrm{w}_{2}\right) .^{27}$ This simple, and well known, formulation of the educational investment decision does not, however, speak to the public nature of most schooling. Public support for secondary school was rarely justified on the basis of positive externalities (e.g., creation of a literate citizenry) the same way that the publicly-supported primary school had been in the nineteenth century. It was, rather, rationalized, often implicitly, on the grounds of capital-market imperfections. Communities were groups of families at different stages of their life-cycle, and publicly-funded education was an intergenerational loan, a means of consumption-smoothing. ${ }^{28}$ The notion can be imbedded in the investment framework

\footnotetext{
${ }^{27}$ Individual high school enrollment decisions are also likely to depend positively on family wealth endowments both through an income effect on the consumption demand for schooling and the easing of capital market constraints (i.e., increased wealth effectively lowers $r$ ).

${ }^{28}$ Becker and Murphy (1988) make a similar point. They go one step further and suggest that the intergenerational loan was paid back in the form of social security. We, on the other hand, are conceptualizing the intergenerational loan as being
} 
through an overlapping-generations model. Using a stark set of assumptions, of which one is that all families (or clans) are identical, the existence of public education is positively related to the income of the older generation, which largely determines the "community budget constraint." The speed with which public education spreads depends on its return, through the expansion of the "community budget constraint."20

All families (or clans) are not identical, however, and the essence of the public-goods problem is the characterization of the majority-voting equilibrium. Rather than have all adult family or clan members earn $\mathrm{w}_{2}$, in the absence of high school, a distribution of $\mathrm{w}_{2}$ can be assumed. The problem, then, is finding a majority-voting equilibrium with respect to both public education and the size of the (income) tax to fund it. Under many scenarios, a wider distribution of $\mathrm{w}_{2}$, given its level, produces less support for public education and lowers the probability that public schooling will pass. ${ }^{30}$ Thus both the level of income and wealth, and their distribution should have been important determinants of public high school education. The extent to which individuals consider themselves members of the same community provides another extension of the public choice framework. Greater social cohesion, intergenerational propinquity, and community stability should have increased the support for publicly funded education. ${ }^{31}$

shifted within the community from one group of grandparents to the next. For an excellent history of the origins of the American public high school, see Reese (1995).

${ }^{29}$ Consider a model identical to that just discussed but in which there are two generations: parent and youth. Each generation requires $w_{t}$ as subsistence in each period. If the return to high school exceeds $r$, then the only constraint on schooling is the "community budget constraint." Assume that all income in excess of "subsistence" goes to schooling, and that the right to attend school is distributed by lottery. The fraction of the children of generation $n$ who attend high school is then given by $\alpha_{n}=\alpha_{1}\left(1+\gamma+\gamma^{2}+\ldots+\gamma^{n}\right)$, where $\gamma=\left(E_{2}-w_{2}\right) /\left(C+w_{1}\right)$ and $\alpha_{1}=\left(w_{2}-w_{1}\right) /\left(C+w_{1}\right)$.

30 See Epple and Romano (1996), who analyze the level of support, and Fernandez and Rogerson (1995), who investigate the existence of public education.

\footnotetext{
${ }^{31}$ Alesina, Baqir, and Easterly (1997) show in a majority-voting model that an increase in the polarization of preferences conceming spending on public goods (formally an increase in the median distance from the median) reduces the amount of public goods provision. They find, using a cross-section of U.S. cities c. 1990, a negative relationship between spending on "productive" public goods (schooling, roads, and libraries) and the city's degree of ethnic fragmentation.
} 
In sum, we postulate a reduced-form equation for the high school enrollment (or graduation) rate in a jurisdiction of the form:

$$
H S=H S\left[\left(w_{1}+C\right) / w_{2},\left(E_{2} / w_{2}\right), r, \bar{Y}, \sigma_{Y}, X\right]
$$

where $\bar{Y}$ and $\sigma_{\mathrm{Y}}$ measure the mean and dispersion of income (or wealth), and $\mathrm{X}$ summarizes the stability, cohesion, and intergenerational propinquity of the community.

\section{State-level Regressions}

In the empirical analysis at the state level we analyze the determinants of high school graduation rates in two years $(1910,1928)$ and of changes in graduation rates across two eras (1910 to $1928 ; 1928$ to 1938 ). The variables we use come as close as we can to capturing the key determinants of familylevel education decisions and those factors relevant in a public choice framework.

All youths are assumed to face the same (national) market for white-collar employment conditional on receiving a high school degree, although the majority were tied to their homes of origin for their school years. ${ }^{32}$ Thus, we do not include a variable for the earnings of local white-collar workers $\left(\mathrm{E}_{2}\right)$, since they are assumed to be the same for all. But we do include variables to account for the opportunity cost of schooling for youth $\left(\mathrm{w}_{1}\right)$ and local blue-collar earnings for adults without high school education $\left(\mathrm{w}_{2}\right)$. Since remunerative employment opportunities for older youth in this period were likely to be found in manufacturing, we proxy the opportunity cost of high school education by the fraction of the work force in manufacturing and by the manufacturing wage.

Various measures of income and wealth (state income per capita, taxable wealth per capita, and

\footnotetext{
${ }^{32}$ One empirical justification for this assumption is that the eamings of white-collar workers were far more similar across the United States than were the earnings of production workers in the 1909 to 1919 period. This continues to be the case. The coefficient of variation of city-level mean clerk wages is smaller than that for production workers in a sample of 227 nonsouthem cities in 1919. Similar patterns are apparent in 1909 and 1914. See Goldin and Katz (1995) for a description of the data which come from the U.S. census of manufactures.
} 
agricultural income per agricultural worker) are available to proxy for household capital-constraints and the consumption demand for education. The return to high school was likely to have been greater where more publicly-supported colleges were available and we include, in the change regression for 1910 to 1928 , a variable for the public university enrollment rate in the initial year.

The public decision to build and staff high schools is more complicated. The frameworks we have cited emphasize the distribution of wealth, the stability of community, and social distance or propinquity. The social stability of communities can be inferred, in part, from the proportion elderly in the state. Social distance or propinquity can be proxied by variables relating to fraction foreign born or Catholic. ${ }^{33}$

The distribution of income or wealth is a more difficult variable to measure across states, but automobile registrations per capita is a good substitute for more obvious measures which do not exist for the years under examination. Automobile registrations per capita, for the period we consider, can be viewed as a count of the fraction of people who were wealthy enough to afford a car. Comparing two states with the same mean wealth, the state with the more compressed distribution will have a greater fraction of households with automobiles, given a level of wealth sufficiently high for the fraction to be positive. Automobile registrations per capita, therefore, summarizes mean wealth and its distribution in a convenient form relevant to voting models of public choice, since it proxies the share of voters likely to be wealthy enough to favor financing an expensive public good such as high schools.

With 48 observations we have had to be judicious in our inclusion of variables, many of which are highly correlated. For example, the fraction manufacturing workers, urban, foreign born, and

\footnotetext{
${ }^{33}$ We have also divided non-Catholics into two other groups: non-hierarchical religions that encourage the reading of the bible by the laity (e.g., Lutherans) and non-hieranchical ones that did not (e.g., most evangelical religions). Only the percentage Catholic is of statistical and economic significance. Race is another important factor in U.S. educational history. But given the large percentage of blacks living in the South in the 1910 to 1940 period, there is little systematic relationship between percentage non-white and graduation mates once measures of income and wealth and a South dummy are included in the statelevel regressions.
} 
Catholic are strongly collinear, as are per capita wealth, income, agricultural income, and automobile registrations. We use a subset of each of these groups in the regressions. Where only one of the many variables mentioned is included, the results are robust to the inclusion of the others. ${ }^{34}$ The estimations are admittedly of the reduced-form variety, but are extremely suggestive of the forces that encouraged and impeded secondary-school education. Table 3 summarizes the main results. Three of the columns $(1,3$, and 4$)$ give levels regressions and three, $(2,5$, and 6$)$, give change regressions. ${ }^{35}$

The association between the key factors of our framework and high school graduation rates in 1910, at the start of the high-school movement, are summarized in the regression in col. (1). Per capita wealth (in 1912), the proportion elderly (in 1910), the percentage of the labor force in manufacturing (in 1910), the percentage Catholic (in 1910), and dummy variables for the South and New England are strong predictors of high school graduation and together they account for almost 90 percent of the cross-state variation.

Wealth (or income, or agricultural income) increases high school graduation, so that moving from being the state at the 25 th percentile to that at the 75 th percentile increases the graduation rate by about 1.5 percentage points (or by 17 percent around the mean). But having more manufacturing is a drag on graduation, such that movement from the 25 th to the 75 th percentile reduces the graduation rate by 1 percentage point (or by 11 percent of the mean). The greater the proportion elderly, the higher is the graduation rate. This strikingly strong positive relationship between high school graduation rates and percent elderly at the dawn of the high school movement (a raw correlation of 0.79 ) is illustrated in Figure 5, panel A. We attribute the effect to the stability of community and not

\footnotetext{
${ }^{34}$ In constructing Table 3, we simply chose variables from these groups to illustrate the role that each played.

${ }^{35}$ The estimates in cols. (1) to (4) are unweighted. These results are not very sensitive to whether we weight by state population. Cols. (5) and (6) are weighted by the population of 17 -year olds in each state. Unweighted estimates of models to explain the change in high school graduation rates from 1928 to 1938 are greatly influenced by two extreme outliers (DE and NV). Thus we present the more robust, weighted estimates.
} 
to differential fertility or immigration, for neither of those variables reduces the positive impact of the elderly. Our finding with regard to the role of the elderly in educational decisions is opposite to that of studies using more recent data (e.g., Poterba 1996) and points to the increased mobility of the elderly in more recent decades. ${ }^{36}$

In col. (3) of Table 3 we examine the determinants of high school graduation rates in 1928 and find similar results to those for 1910, when translated into elasticities. But for 1928 we can include variables that we cannot for 1910 and they add significantly to the story. The most interesting of the new variables is automobile registrations per capita (in 1930). The variable incorporates both the wealth of an area and its distribution, and has a strong positive effect on high school graduation rates even when a direct measure of per capita wealth is included. The specification in col. (3) implies that increasing auto registrations from the state at the 25 th percentile to that at the 75 th percentile increases the graduation rate by 8 percentage points (or by 27 percent of the mean level in 1928). It is a powerful explanatory variable that speaks to the importance of a more equal distribution of wealth, given its mean, in the provision of education as a public good. ${ }^{37}$ The states with the most automobile registrations per capita in 1930, as shown in Figure 5, panel B, CA, NV, KS, IA, and NE, all members of the "educational belt" and all at the very high end of the educational distribution. ${ }^{38}$

Also of interest are the roles of manufacturing as a share of employment, the manufacturing wage, and their interaction as shown in Table 3, col. (4). Having a greater percentage of the labor force

\footnotetext{
${ }^{36}$ Today's elderly can, and do, escape the higher taxation that comes with more and better quality education. In the period we are examining, the elderly generally did not, or could not, move from places with more expensive educational public goods. Grandparents who lived in towns and villages at the tum of this century often boarded their grandchildren who lived on farms to enable them to attend high school.

${ }^{37}$ The strong positive impact of automobile registrations per capita on graduation rates is robust to the inclusion of controls for population density, percentage urban, and access to improved roads.

${ }^{38}$ Lindert $(1994,1990)$, in two cross-country studies of the twentieth century, finds that greater equality fosters more social spending (e.g., transfer programs) and that a greater pencentage of Catholics lowers it.
} 
in manufacturing, given the manufacturing wage (and per capita income or wealth), was not a drag on education until the wage exceeded its mean. Similarly, having a higher manufacturing wage was not an impediment to education until the percentage of the labor force in manufacturing exceeded its mean. It was the high manufacturing-wage states in which industry employed a large percentage of the labor force that had low graduation rates (e.g., NJ, NY, PA). The opportunity cost of education had to be high and the availability of such jobs had to be substantial for manufacturing to deter education.

We have also estimated a state fixed-effects model which pools data from 1910, 1920, and 1930 and find similar results to those of the levels regressions in columns (1), (3), and (4). ${ }^{39}$ Auto registrations per capita and the percentage elderly are still strongly and positively related to the state graduation rate even with the inclusion of state fixed effects. Percentage Catholic and the manufacturing employment share variables have coefficients similar to those in the cross-section regressions but they cannot be precisely estimated in a fixed-effects framework due to the persistence of state differences in these variables.

We next analyze the change from 1910 to 1928 , and the results in col. (2) reveal the importance of most of the variables that featured in the levels regression with one addition and one exception. All the independent variables are meant to capture the initial conditions in a state. Thus, more wealth (in 1910) hastened the growth of high schools from 1910 to 1928 , and a greater share of the labor force in manufacturing (in 1910) slowed it. The positive relationship between (log) per capita wealth at the start of the high school movement and the expansion of high schools from 1910 to 1928 is displayed

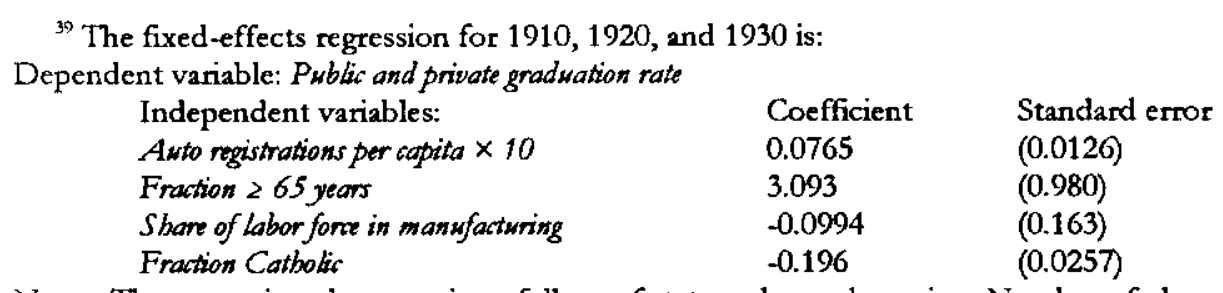

Notes: The regression also contains a full set of state and year dummies. Number of observations $=144 ; \mathrm{R}^{2}=0.959$. Sources: See Table 3. 
in Figure 5, panel C. The regression in Table 3, col. (2) shows, and Figure 5, panel D illustrates, that the fraction of youth in the state who attended public colleges and universities in 1910 increased graduation rates through, we believe, an expansion in the returns to high school. The only variable to change signs is that regarding the elderly.

Finally we analyze the change during the 1930s. The estimation in col. (5) is similarly configured to that for the 1910 s and 1920 s, and the sparse specification in col. (6) focuses on factors unique to the Great Depression. Much appears to have been altered by the 1930 s. Wealth remains an important determinant, but no longer does the fraction of the labor force in manufacturing have a strong negative effect. In fact, manufacturing has a weak positive effect and the Mid-Atlantic states are residually positive. Col. (6) explores these results further and adds the change in unemployment from 1930 to $1940 .^{40}$ Graduation rates increased most, during the 1930 s, in states that underwent the largest increases in unemployment, given their income levels, and in the leading manufacturing states. The 1930s produced greater educational homogeneity among non-southern states, as was seen in Table 1 , by eliminating many jobs that had once occupied teenagers. The Great Depression may ironically have spurred the educational attainment and occupational mobility of the youth of industrial America.

We have not yet mentioned a factor considered by many to be crucial to extending education in to the teenage years - state legal constraints such as compulsory education and child labor laws. Much has been written on compulsory education and whether the laws effectively constrained youth to extend their time in school. Although the bulk of the econometric evidence to date argues that compulsory education laws were passed in states that already had extensive school attendance, some carefully executed studies find some impact, although not necessarily on high school graduation in the

\footnotetext{
* Agricultural income (natural log of) per agricultural worker in 1920 is used here instead of the (log) wealth variable. The results are virtually unchanged if $(\mathrm{log})$ wealth in 1922 is used.
} 
1910 to 1940 period. $^{41}$ The laws in the 1910 s and 1920 s were extremely complex and the binding constraints were often the minimum age and the educational requirements for a work permit, not the maximum age of compulsory education. The econometric evidence to date, although not entirely conclusive, leads us to conclude that the laws had some impact on the education of teenagers, but that the influence on high school graduation was small. ${ }^{42}$

Less attention has been paid to other state laws that were potentially more important than compulsory schooling and child labor laws in influencing early high school expansion. A now-obscure set of state laws, termed "free tuition" laws, probably hastened high school expansion in the 1910s and 1920s. These laws mandated that school districts not containing secondary schools pay the tuition of resident youths who attended school in neighboring districts. Prior to the adoption of the laws, the parents of the youths would have had to pay tuition. The laws appear to have been of importance in the more sparsely-settled states of the Midwest and West. Many of these states adopted "free tuition" laws from 1907 to the 1920 s, some affecting all districts in the state and others constraining only the districts of counties that approved the laws (e.g., NE in 1907 and IA in 1913, both statewide; CA in 1915, county level). We suspect that the laws hastened the spread of secondary schools in those states,

\footnotetext{
${ }^{4}$ See, for example, Edwards (1978), Landes and Solmon (1972), Margo and Finegan (1996), and Schmidt (1996) for the 1870 to 1880 period, and Edwards, for the 1940 s and 1950 s, conclude that compulsory education laws were ineffective. Schmidt, however, in both her work on New York State in the 1920s, and the entire United States in the 1920s and 1930s, cornes to the opposite conchusion, although the effects are often not substantial. She allows for the complexity of the laws in her analysis, and, in her assessment of New York State law, measures the extent of enforcement. Schmidt's, in addition, is the only study that focuses on the impact of the laws on secondary school education. Margo and Finegan, using the 1900 census, also find some impact of compulsory education laws on the schooling of 14-year olds, but only when combined with childlabor legislation. The impact of the laws is identified through an interaction of the laws and quarter-of-birth to remove common factors influencing schooling differences across states.

${ }^{2}$ In 1917, for example, although 30 states had a maximum age of compulsory school of 16 years, all but 4 states granted labor permits at or before age 14 and the remaining 4 granted them at age 15 . The education required for a labor permit was no where more than 8 years and was exactly 8 years in just 5 states. In 1928 the maximum age of compulsory schooling had increased to 18 in 5 states and to 17 in another 5 states. But labor permits were still issued to those under 16 years of age in all but 2 states and the education required for a labor permit was no where greater than 8 years. The laws, therefore, do not appear to have constrained youths to remain in high school, let alone to have graduated from high school. See U.S. Department of Education, Biennials 1916-1918; Keesecker (1929).
} 
but we have not examined the subject in depth. ${ }^{43}$

At the start of the high school movement in 1910, Americans were still a predominantly rural people. One-half lived in places that either were unincorporated or had fewer than 1,000 persons. Almost one-third lived in cities of more than 25,000 , and the remainder lived in small cities, towns, and villages. In 1910 and 1920, those in that latter group educated their children for the most years. The larger cities had the lowest schooling rates for teenagers, lower still than were those in the open country. ${ }^{44}$ The cities provide yet another laboratory in which to study the factors that hindered and fostered the transition to secondary school, for they offer a considerably wider set of variables.

\section{City-level Regressions}

Our sample contains data from more than 200 cities, all those with populations exceeding 10,000 in 1910 outside the South because of data problems relating to segregated schools. As in the state-level analysis, a simple human-capital model motivates the inclusion of variables and the

\footnotetext{
${ }^{43}$ An interesting question is why the citizens of a state, in districts that already had high schools, cared that other districts did not tax their citizens for high school education. If voting in the state legislature were based on the population of the state, it must have been the case that the citizens of the districts with high schools wanted to constrain the behavior of those without. There are various possibilities. One is ideological. Another is that town and village high schools were crowded with youths from the open country who boarded with relatives to avoid tuition payments. Yet another is that districts that imposed higher taxes to support their schools wanted to prevent their older residents from escaping higher rates by moving across districts. This possibility seems less likely. By 1925 virtually all non-southem states had a form of "free tuition" legislation (Hood 1925).

${ }^{44}$ We use the 1910 and 1920 PUMS to construct estimates of the school attendance rates of 16 and 17 -year olds. School attendance is defined here to include only those who attended school and who were not also employed for pay or by their families. The restriction eliminates many who went to school for brief periods or who did not attend day schools. We find the following for areas outside the South:

$\% 16 \& 17$-year olds attending school, non-South U.S.

$\begin{array}{lll} & 1910 & 1920 \\ \text { Rural [unincorporated or }<1,000] & 37.7 \% & 38.7 \% \\ \text { Town }[1,000<10,000] & 40.5 & 43.9 \\ \text { Small city }[10,000<25,000] & 36.9 & 35.1 \\ \text { City }[>25,000] & 26.1 & 31.7 \\ \quad \text { Medium }[25,000<100,000] & 31.5 & 35.9 \\ \quad \text { Large }[>100,000] & 24.0 & 30.1\end{array}$

The 1910 sample contains 9,607 observations and that for 1920 has 11,955 . A similar pattern is apparent, but modestly attenuated, in a linear probability model of full-time enrollment (enrolled but not employed) with controls for census division and dummy variables for race, sex, foreign-bom status, parents' foreign-born status, and father's occupational group. See also Greene and Jacobs (1992) who report similar results for 1910.
} 
estimation is, once again, of a reduced-form nature. The dependent variable comes from a different set of sources than did that for the state-level analysis and refers to the attendance of youth (15 to 17 , or 16 to 17 -years old) in any school. Thus the dependent variable does not necessarily refer to attendance in high school. The data derive from the U.S. population census, and although they are generally overstatements of the actual rate of school-going among youths, they appear to be reasonable measures of differences across cities in schooling. ${ }^{45}$

The city-level results (in Table 4) tell many of the same stories as did those at the state-level. Manufacturing, measured by the fraction of production workers in the population, has a strong negative effect, and industries known to have hired unskilled and child workers add to it. Note the large negative effects of textiles and clothing, as well as chemicals which included the low-skilled fertilizer industry. Although the variable indicating the percentage child workers in manufacturing in 1910 is rather tautological for the 1910 regression, its importance in 1920 (and that of the 1920 variable in 1930) speaks to the effect of certain industries on the opportunity cost of youth, the capital-constraints of their parents, and a possible myopia regarding education engendered by particular industrial settings. The fraction foreign born, Catholic, and non-white each have a strong negative relationship with attendance. ${ }^{46}$ But when fraction foreign born and Catholic are entered together, the coefficient on

\footnotetext{
${ }^{45}$ The U.S. federal population census in 1910,1920 , and 1930 asked whether an individual had attended school at least one day during the preceding year. Attendance could have been at a night, correspondence, industrial, music, commercial, private, parochial, or regular-day school, among others. Another measure is available for our group of cities, but it also has problems. It derives from the same sources that produced the state-level measure and gives average daily attendance in the school district, which was almost always the entire city. The problem is that families living just outside the city, in areas without a high school, often went to the schools in the city (tuition was sometimes paid by the student's school district or parents). To convert the attendance data into a rate, the city's population of 14 to 17 -year olds must be used, but it will, on occasion, be too small. Over time, we can observe lange changes in the rates of some cities, possibly reflecting the opening up of high schools in neighboring communities and thus the reduction in attendance in the city. Empirical findings concerning the correlates of city high school attendance rates and city characteristics are quite similar for both the census enrollment rate measure and the city average daily attendance rate measure for the sub-sample of cities with reasonable average daily attendance data.

${ }^{46}$ Following Alesina, Baqir and Eastery (1997), we have explored the relationship between city enrollment rates and ethnic factionalization (measured by 1 minus the Herfindahl index of ethnic group population shares) in 1920 using a decomposition of the population of each city into 14 ethnic groups based on race and parents' birthplaces. Ethnic factionalization is strongly and negatively correlated with enrollment rates for 16 to 17 -year olds in northern cities in 1920 . But it is also highly correlated
} 
foreign born is either insignificant or, as in the 1930 results, positive. Wealth per capita is positively related to education. Population density, reflecting the greater poverty of the denser cities, is negatively related to school attendance. High school density, a variable we cannot construct at the state level, has a strong positive effect, showing the importance of proximity to schools, even in cities. ${ }^{47}$ Interestingly, the 1930 regression suggests that replacing a regular high school with a vocational one would increase attendance by 1.5 percentage points.

The residual effect of region underscores and extends what we noted before in the raw data. At the start of the high school movement, New England and the Pacific states were in the forefront, and their schooling rates far exceeded those in the rest of urban America. But after two decades of educational expansion nationally, urban New England, holding constant a host of other factors, was left behind as were the urban areas of the Mid-Atlantic. The Great Depression would later even out many of these differences, but for some time the Far West was considerably ahead, as were the many towns, villages, and small cities of the Midwest and Plains states. We have no measure of distribution in this data set, but we suspect that it served the same role it appears to have at the state level, as a factor fostering the growth of educational institutions and of schooling.

\section{IMPLICATIONS FOR CROSS-COUNTRY DIFFERENCES AND FOR ECONOMIC GROWTH}

Our motivation has been twofold: to understand the extraordinary spread of secondary education in the United States, and to use those insights to make sense of the large and growing differences in the twentieth century between secondary-school expansion in the New World and in the economically-leading countries of early twentieth-century Europe.

with percentage foreign born and percentage Catholic and is insignificant when either is included in the enrollment model.

${ }^{47}$ We cannot construct it because the school data appear deficient for many states, probably because some elementary schools included high school instruction. 
Schooling differences within the United States suggest the importance of the level as well as the distribution of wealth, and the level as well as the composition of manufacturing employment. They hint to the importance of cultural and religious homogeneity among people and stability of community. And they suggest that state expenditures on public colleges and universities created a powerful incentive for youths to graduate from high school. We do not know, however, what stronger state or national control relative to the local governments would have achieved for in all American states educational funding was mainly at the local level in the period under consideration. In 1925, for example, localities raised 84 percent of the revenue for $\mathrm{K}-12$ education; states, counties, and the federal government funded just 16 percent together (U.S. Department of Education Biennials 1924-1926).

Thus many of the features of America that made it an egalitarian haven in the first part of the nineteenth century, allowed it to expand its education in the twentieth, even after a large inequality of material condition had emerged. In the 1920 s when inequality of non-agricultural income was probably at its high-point for the century, local governments funded an expensive transition that would soon lead to nearly universal secondary school education.

The aristocratic features of Europe that led many to abandon it for America, on the other hand, hindered the spread of secondary education for some time. In England and Wales, education beyond grammar school was, until 1944 , either privately provided and funded or partially funded by the government. Secondary schooling was, most often, preparatory training for the university, but higher education was not publicly funded. Students in Germany, France, and Great Britain were tracked before their teenage years with only some allowed to continue to secondary school and then university.

Although the United States was becoming a vastly unequal economy by the early twentieth century, several factors encouraged publicly-funded secondary school education. One was local provision. The poor were regionally distinct (southem incomes were half those nationally in 1920) and 
they were also locationally distinct within regions (the foreign bom, particularly from the newer sending countries, were far more urbanized than were native-born whites). Thus the average school district, with the exception of those in large urban areas, contained a relatively homogeneous group of citizens. In most European countries, on the other hand, where decision-making was at the national, state, or provincial level, the broader distribution of income and wealth militated against publicly-funded secondary school education. Inequality of material condition appears to have perpetuated Old World institutions that, for some time, reinforced the existing distribution. As in various models of educational finance, this appears to be a classic case of the "ends against the middle" (Epple and Romano 1996; Fernandez and Rogerson 1995).

But there is another factor, far harder to identify, that set American education in the early twentieth century apart from that in Europe. America simply had a stronger tradition of egalitarian institutions and impulses emphasizing equality of opportunity and they survived the reduction in equality of material condition. These institutions were, and continue to be, represented by the statefinanced colleges and universities of the Midwest and West, to be contrasted to not just the elite institutions of Europe but also to their far less distinguished counterparts in the Northeast.

But what did the high school movement signify for economic growth within the United States and between America and Europe? A large literature links economic growth to a more educated populace either because educated people are more productive or because education indirectly increases growth through a variety of routes (Barro 1997). Our state-level data allow a suggestive, although not conclusive, exploration of the relationship.

Per capita income converged substantially across the states, particularly after the 1930s (Barro and Sala-I-Martin 1991). Convergence forces were so powerful that they appear to leave little else to account for differences in per capita income growth. Yet, in a convergence equation for the 1929 to 
1947 period, the public high-school enrollment rate in 1928 has a significant, positive, and strong effect on the growth of income, whereas the proportion urban or manufacturing has a negative effect. Higheducation states in the 1920 s had income per capita that grew faster than did that in other states, given initial levels. ${ }^{48}$ We do not yet have an answer to a related question of larger significance, whether the substantial differences between education in the United States and in Europe are part of what differentiated the interwar and post-World War growth experiences of these economies.

The increase in secondary school education for much of the twentieth century can account for about 70 percent of the increase in the educational stock of Americans (Goldin 1997). It was high school, not college, that led to the largest expansion of educational attainment before the 1970s. Many of the "super-education" states of the era have continued to be among the top educational performers today (with the sad exception of California). Why the United States has begun to fall behind many countries in the quality of its secondary-school education may be rooted, ironically, in the virtues that early in the twentieth century led to the expansion of high schools that were open to all, publicly funded and provided, and largely forgiving in their standards for advancement.

\footnotetext{
${ }^{48}$ The estimates are robust to weighting, or not, and to the inclusion of other measures of initial education such as the graduation rate, public or total. We admit, though, that any of the strong explanatory variables for education (such as automobile registrations per capita) are also equally grod predictors of the residual variance in the convergence equation. A representative convergence regression follows. The relationship remains, but is weaker, for the longer 1929 to 1959 period. Dependent variable: Log(income per capita 1947/income per capita, 1929); weighted mean $=0.660$ Independent variables: Coefficient Standard error Log(per capita income, 1929) $\quad-0.357 \quad(0.0710)$ Public enrollment rate, $1928 \quad 0.317 \quad(0.0819)$

Percent urban, $1930 \quad-0.219 \quad(0.126)$

Constant $2.96 \quad(0.377)$

Notes: Number of observations $=48 ; \mathrm{R}^{2}=0.912$. Regression is weighted by the state's adult population in 1930 . Sources: Public enmllment rate, 1928: Goldin (1994, 1997). Per capita income 1929, 1947: U.S. Department of Commerce (1984). Percent urban, 1930: U.S. Bureau of the Census (1975).
} 


\section{REFERENCES}

Alesina, Alberto, Reza Baqiir, and William Easterly. 1997. "Public Goods and Ethnic Divisions." National Bureau of Economic Research Working Paper No. 6007 (April).

Barro, Robert J. 1997. Determinants of Economic Growth: A Cross-Country Empirical Study. Cambridge, MA: MIT Press.

Barro, Robert J. and Xavier Sala-I-Martin. 1991. "Convergence across States and Regions," Brookings Papers on Economic Activity, vol. I. Washington, D.C.: The Brookings Institution: 107-82.

Becker, Gary S., and Kevin M. Murphy. 1988. "The Family and the State," Journal of Law and Economics 31 (January): 1-18.

Board of Education for England and Wales. 1932. Education in 1931. London: His Majesty's Stationery Office.

Carr-Saunders, A.M., D. Caradog Jones, and C.A. Moser. 1958. A Sunvy of Social Conditions in England and $W$ ales. Oxford: Clarendon Press.

Dewhurst, J. Frederic, John O. Coppock, P. Lamartine Yates, and Associates. 1961. Europe's Needs and Resources: Trends and Prospects in Eighteen Countries. New York: Twentieth Century Fund.

Easterlin, Richard. 1981. "Why Isn't the Whole World Developed?" Joumal of Economic History 51 (March): 1-19.

Edwards, Linda Nasif. 1978. "An Empirical Analysis of Compulsory Schooling Legislation, 1940 to 1960," Joumal of Law and Economics, 21 (April): 203-22.

Epple, Dennis and Richard E. Romano. 1996. "Ends Against the Middle: Determining Public Service Provision When There Are Private Alternatives," Journal of Public Economics 62 (November): 297-326.

Fernandez, Raquel, and Richard Rogerson. 1995. "On the Political Economy of Education Subsidies," Review of Economic Studies 62 (April): 249-62.

Goldin, Claudia. 1994. "Appendix to: How America Graduated From High School: An Exploratory Study, 1910 to 1960," National Bureau of Economic Research-Development of the American Economy Working Paper No. 57 (June).

Goldin, Claudia. 1997. "America's Graduation from High School: The Evolution and Spread of Secondary Schools in the Twentieth Century." Unpublished paper, Harvard University.

Goldin, Claudia, and Lawrence F. Katz. 1995. "The Decline of Noncompeting Groups: Changes in the Premium to Education, 1890 to 1940," National Bureau of Economic Research Working Paper No. 5202 (August). 
Goldin, Claudia, and Lawrence F. Katz. 1997. "Education and Income in the American Heartland: Iowa, 1915." National Bureau of Economic Research Summer Institute, July.

Greene, Margaret E., and Jerry A. Jacobs. 1992. "Urban Enrollments and the Growth of Schooling: Evidence form the U.S. 1910 Census Public Use Sample," American Journal of Education 101 (November): 29-59.

Hood, William R. 1925. Legal Provisions for Runal High Schools. U.S. Bureau of Education, Bulletin No. 40. Washington, D.C.: G.P.O.

Hoxby, Caroline M. 1996. "Are Efficiency and Equality in School Finance Substitutes or Complements?" Journal of Economic Perspectives 10 (Fall 1996): 51-72.

Iowa Department of Public Instruction. 1916-1918. Iowa School Report. Des Moines, IA.

Keesecker, Ward W. 1929. Laws Relating to Compulsory Education, U.S. Bureau of Education Bulletin No. 20. Washington, D.C.: GPO.

Krug, Edward A. 1964. The Shaping of the American High School: 1880-1920. Madison, WI: University of Wisconsin Press.

Krug, Edward A. 1972. The Shaping of the American High Schoot Volume 2 1920-1941. Madison, WI: University of Wisconsin Press.

Kuznets, Simon, Ann Ratner Miller, and Richard A. Easterlin. 1960. Population Redistribution and Economic Growth: United States, 1870-1950. VoL II. Analyses of Economic Change. Philadelphia, PA: The American Philosophical Society.

Landes, William, and Lewis Solmon. 1972. "Compulsory Schooling Legislation: An Economic Analysis of Law and Social Change in the Nineteenth Century," Journal of Economic History 32 (March): 45-91.

Lindert, Peter. 1994. "The Rise of Social Spending: 1880-1930," Explorations in Economic History 31 (January): 1-37.

Lindert, Peter. 1996. "What Limits Social Spending?," Explorations in Economic History 33 (January): 1-34.

Maddison, Angus. 1987. "Growth and Slowdown in Advanced Capitalist Economies: Techniques of Quantitative Assessment," 25 Journal of Economic Literature (June): 649-98.

Maddison, Angus. 1991. Dynamic Forces in Capitalist Development: A Long-Run Comparative View. Oxford: Oxford University Press.

Margo, Robert A., and T. Aldrich Finegan. 1996. "Compulsory Schooling Legislation and School Attendance in Turn-of-the-Century America: A Natural Experiment' Approach," National Bureau of Economic Research-Historical Series Working Paper No. 89 (July). 
Matthews, R.C.O., C.H. Feinstein, and J.C. Odling-Smee. 1982. British Economic Growth 1856-1973. Stanford, CA: Stanford University Press.

Matthews, Roderick Donald. 1932. Post-Primary Education in England. Ph.D. dissertation, University of Pennsylvania, Philadelphia.

Mitchell, B.R. 1992. International Historical Statistics: Europe, 1750-1988. New York: Stockton Press.

Nelson, Richard and Gavin Wright. 1992. "The Rise and Fall of American Technological Leadership," Journal of Economic Literature 30 (December): 1931-64.

Olson, Keith W. 1974. The G.I. Bill, the Veterans, and the Colleges. Lexington, KY: The University Press of Kentucky.

Phelps Brown, E.H. 1977. The Inequality of Pay. Oxford: Oxford University Press.

Poterba, James. 1996. "Demographic Structure and the Political Economy of Public Education." National Bureau of Economic Research Working Paper No. 5677 (July).

Reese, William J. 1995. The Origins of the American High School. New Haven CT: Yale University Press.

Ringer, Fritz K. 1979. Education and Society in Modern Eumpe. Bloomington IN: Indiana University Press

Schmidt, Stefanie. 1996. "Compulsory Education Laws and the Growth of American High School Attendance, 1914-1934: Evidence from the 1940 Census and a Case Study of New York State." Paper presented at the Cliometrics conference, Nashville, TN, May 1996.

U.S. Bureau of the Census. 1912. Thirteenth Census of the United States: 1910. Population. Washington, D.C.: GPO.

U.S. Bureau of the Census. 1913. Census of Manufactures, 1909. Washington, D.C.: GPO.

U.S. Bureau of the Census. 1923. Fourteenth Census of the United States: 1920. Population. Washington, D.C.: GPO.

U.S. Bureau of the Census. 1923a. Census of Manufactures, 1919. Washington, D.C.: GPO.

U.S. Bureau of the Census. 1927. Financial Statistics of Cities, 1925. Washington, D.C.: GPO

U.S. Bureau of the Census. 1932. Fifteenth Census of the United States: 1930. Population. Vol. III. Washington, D.C.: GPO.

U.S. Bureau of the Census. 1932a. Financial Statistics of Cities, 1930. Washington, D.C.: GPO.

U.S. Bureau of the Census. 1933. Census of Manufactures, 1929. Washington, D.C.: GPO. 
U.S. Bureau of the Census. 1975. Historical Statistics of the United States: Colonial Times to 1970. Washington, D.C.: GPO.

U.S. Department of Commerce. 1926. Statistical Abstract of the United States, 1925. Washington, D.C.: GPO.

U.S. Department of Commerce. 1930. Religious Bodies: 1926. Volume I: Summary and Detailed Tables. Washington, D.C.: GPO.

U.S. Department of Commerce. Bureau of Economic Analysis. 1984. State Personal Income by State: Estimates for 1929-1982. Washington, D.C.: GPO.

U.S. Bureau of Education. [various years]. Biennial Reports of the Commissioner of Education [year]. Washington, D.C.: GPO.

U.S. Department of Education. [various years]. Education Repont [year]. Washington, D.C.: GPO.

U.S. Department of Education. 1993. 120 Years of American Education: A Statistical Portrait. Washington, D.C.: GPO.

Urquhart, M.C., and K.A.H. Buckley. 1965. Historical Statistics of Canada. Cambridge: Cambridge University Press. 
Figure 1: Secondary School Enrollment and Graduation Rates: Entire United States

Source: U.S. Department of Education (1993).

Notes: Enrollment figures are divided by the number of 14 to 17-year olds; graduation figures are divided by the number of 17-year olds. Total includes both males and females in public and private schools (excluding preparatory departments in colleges and universities).

Public and Private Secondary School Rates

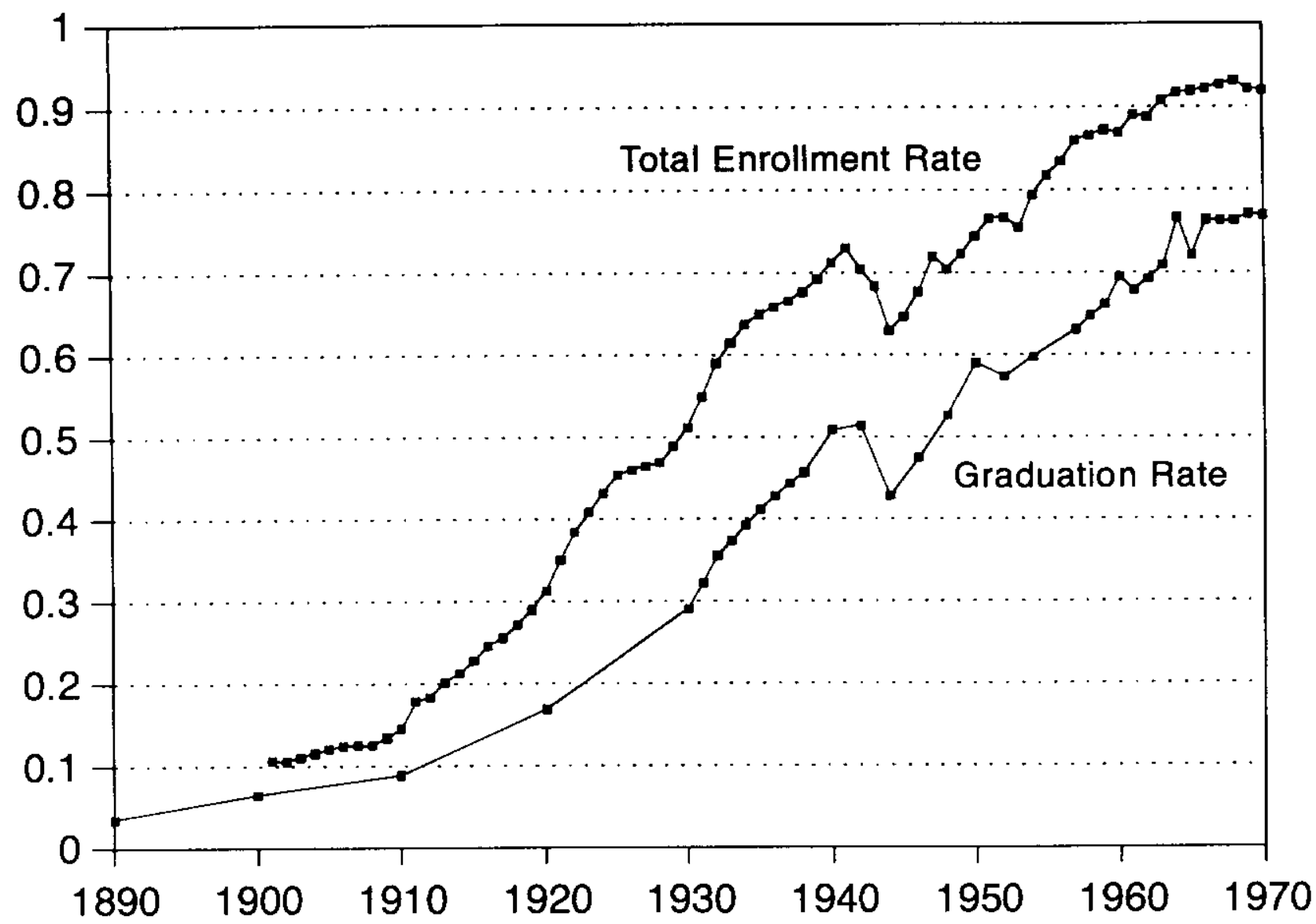


Figure 2: Total (Public and Private) High School Graduation Rates for Six Northern and Western Regions

Sources: State-level high school graduation data set from various sources; see Goldin $(1994,1997)$.

Notes: Males and females are combined. The number of graduates is divided by the approximate number of 17-year olds in the states. Constant growth rate interpolations of population data are made between census years.

\section{Graduation Rate}

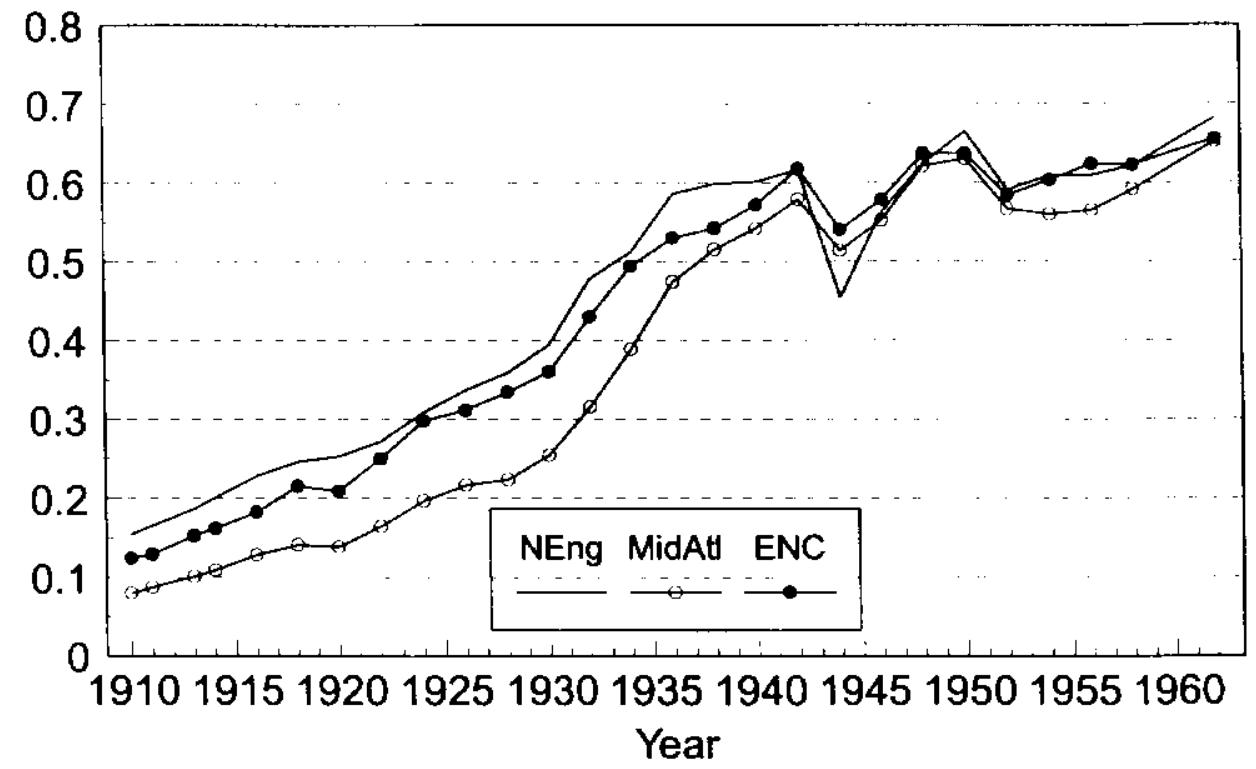

Graduation Rate

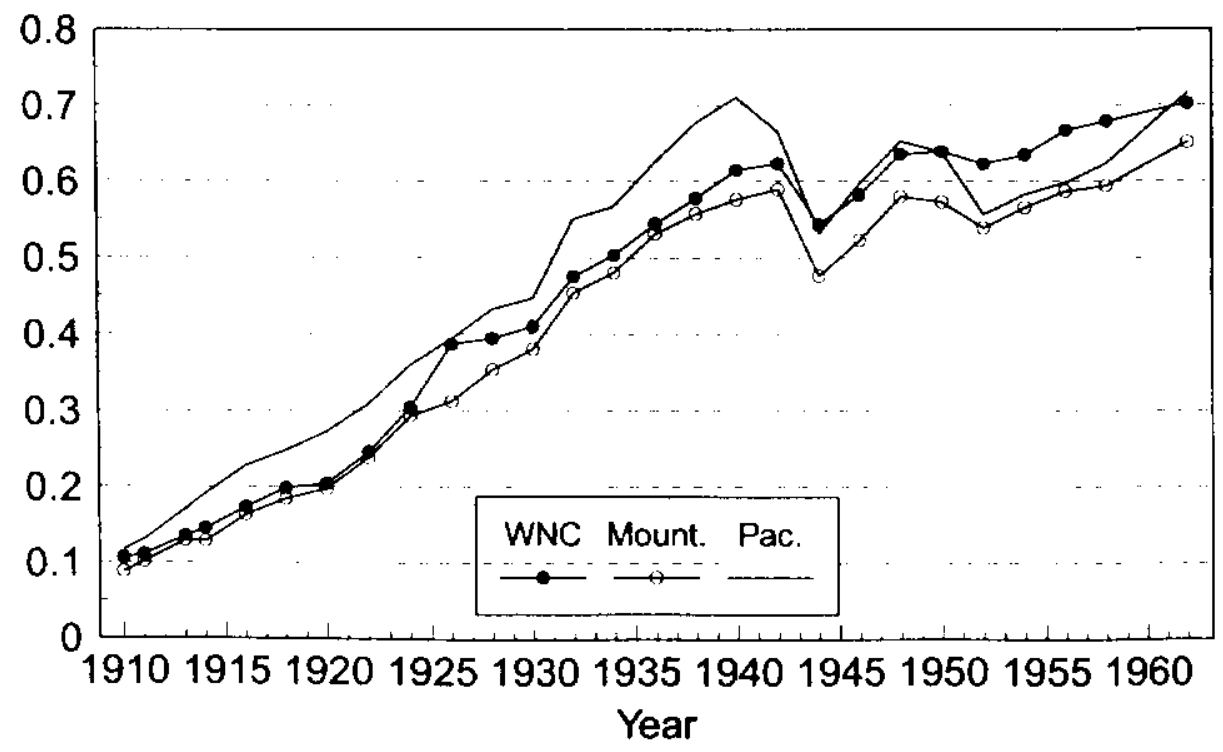


Figure 3: Public and Private High School Graduation Rates for Two Southern and One Northern Region: 1910 to 1962

Sources: State-level high school graduation data set from various sources; see Goldin $(1994,1997)$.

Notes: Males and females are combined. The number of graduates is divided by the approximate number of 17-year olds in the states. Constant growth rate interpolations of population data are made between census years.

\section{Public \& Private HS Graduation Rate}

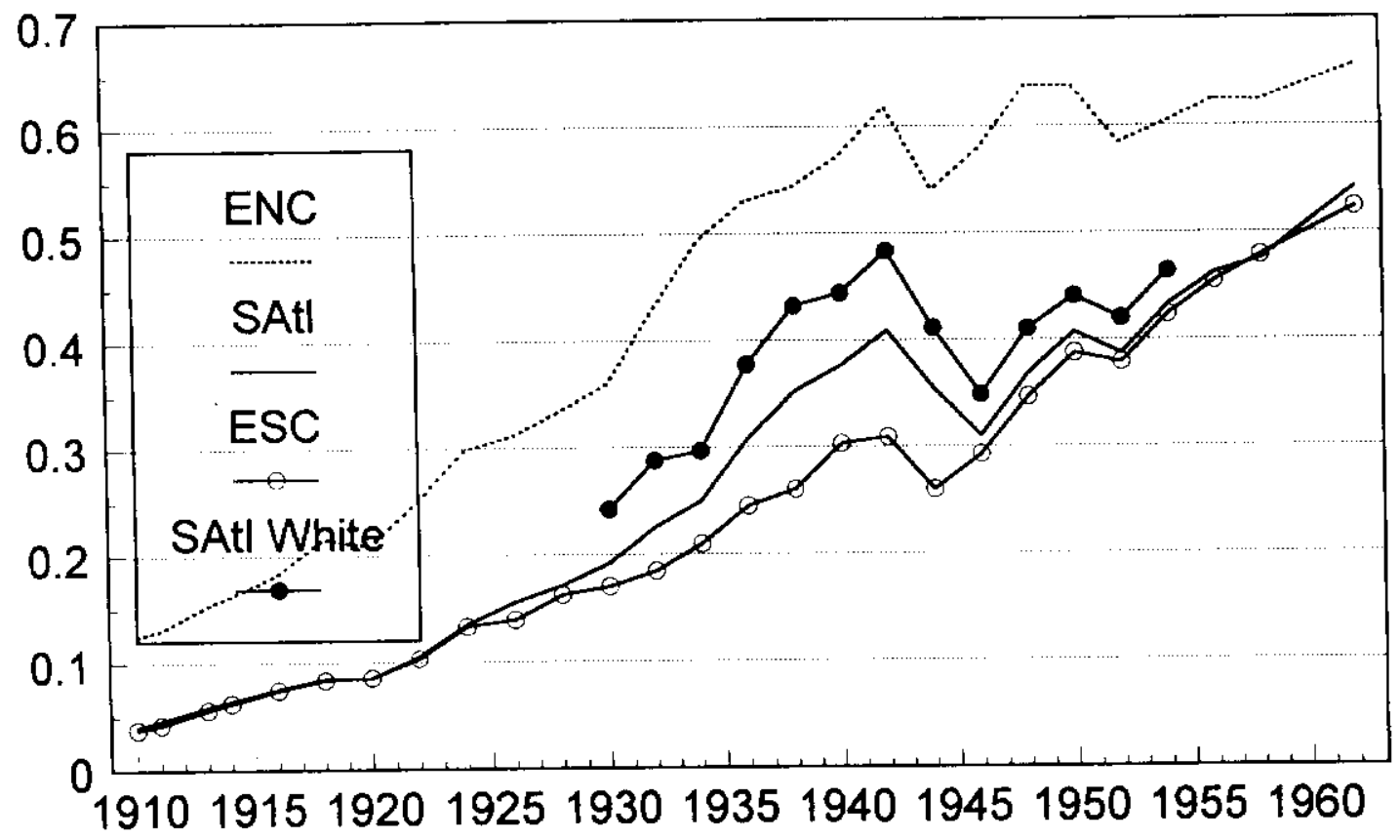




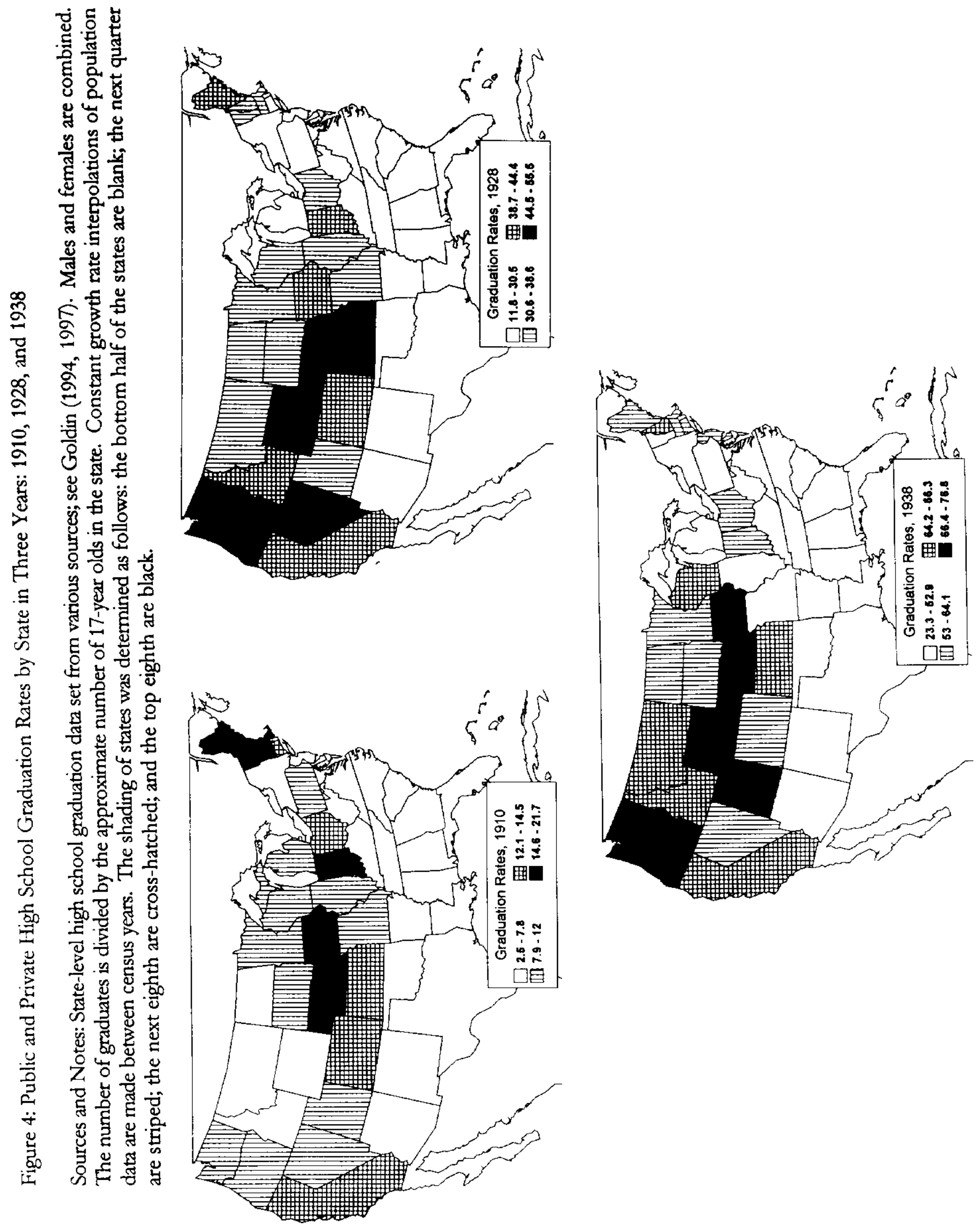



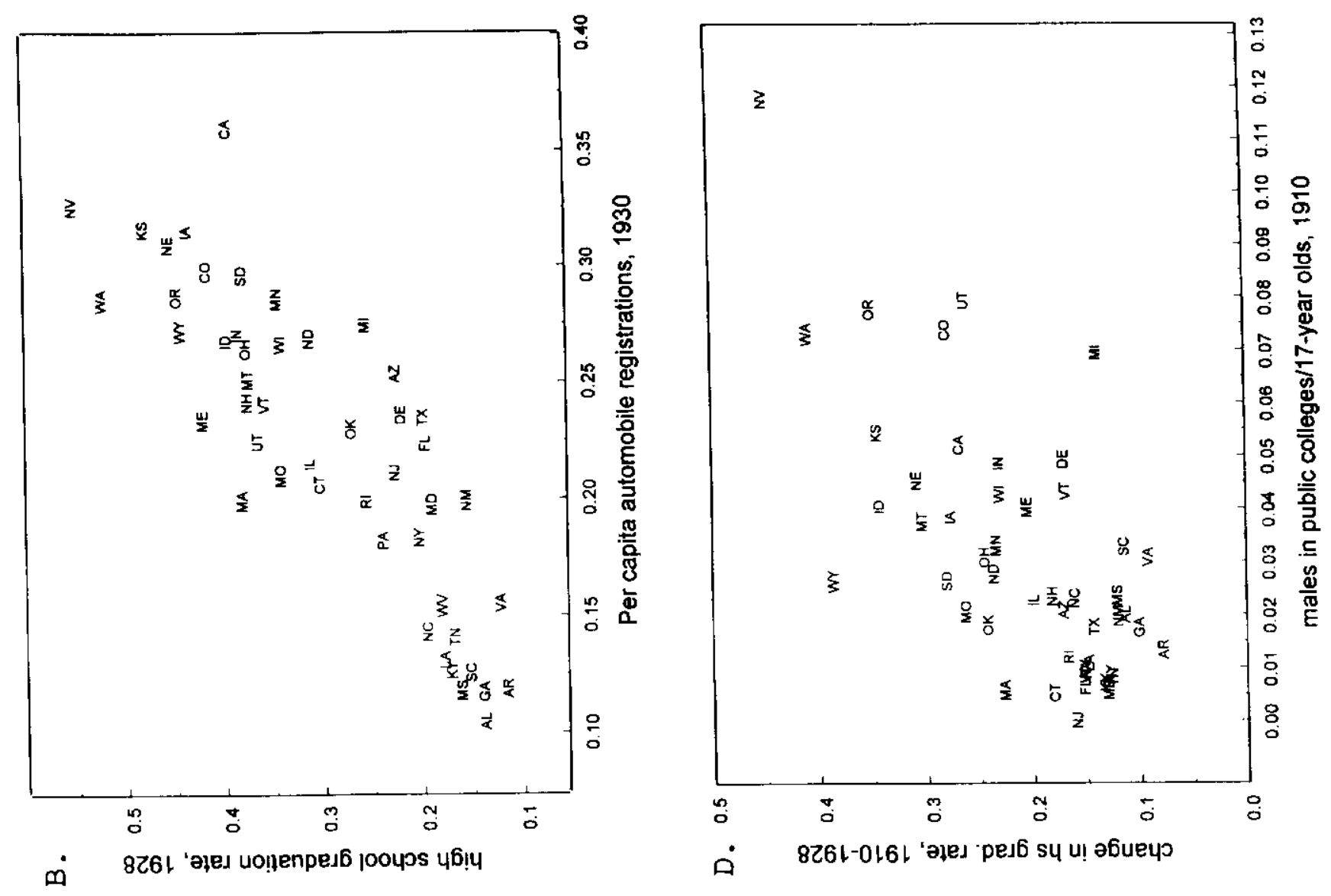

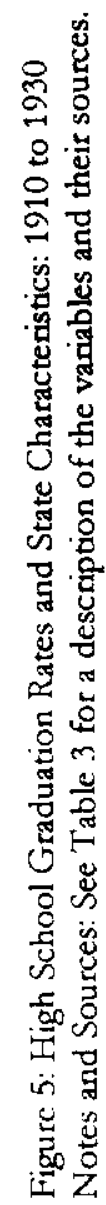
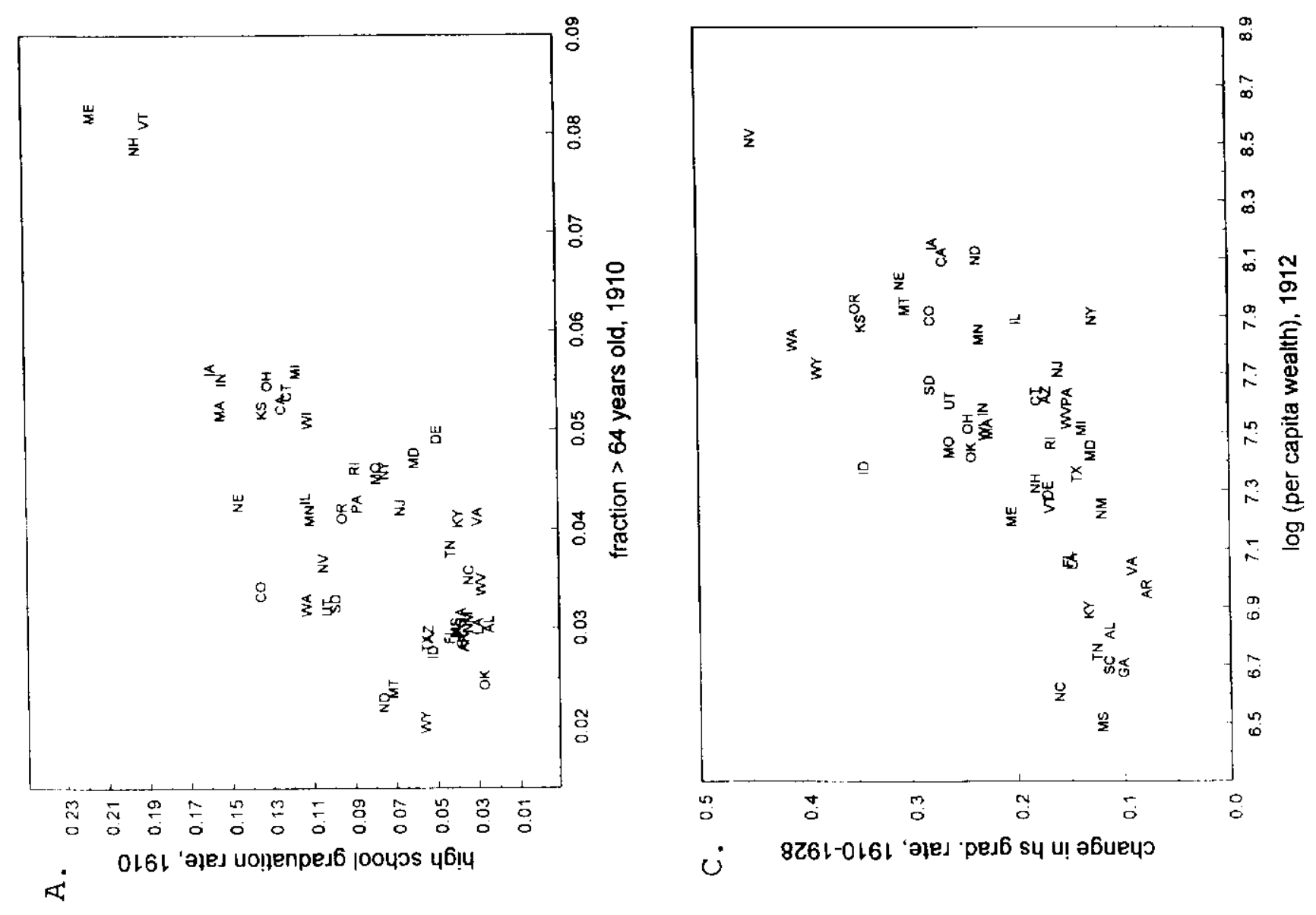
Table 1

High School Graduation Rates, Summary Statistics by State

\begin{tabular}{|c|c|c|c|c|c|c|}
\hline & \multicolumn{3}{|c|}{ Unweighted } & \multicolumn{3}{|c|}{ Weigbted } \\
\hline & Mean & $\begin{array}{l}\text { Standard } \\
\text { deviation }\end{array}$ & $\begin{array}{c}\text { Coefficient of } \\
\text { variation }\end{array}$ & Mean & $\begin{array}{l}\text { Standard } \\
\text { detiation }\end{array}$ & $\begin{array}{c}\text { Coefficient of } \\
\text { variation }\end{array}$ \\
\hline & \multicolumn{6}{|c|}{48 States } \\
\hline 1910 & 0.088 & 0.049 & 0.557 & 0.086 & 0.043 & 0.500 \\
\hline 1920 & 0.180 & 0.085 & 0.472 & 0.162 & 0.069 & 0.426 \\
\hline 1928 & 0.300 & 0.117 & 0.390 & 0.270 & 0.100 & 0.370 \\
\hline \multirow[t]{2}{*}{1938} & 0.504 & 0.145 & 0.289 & 0.482 & 0.130 & 0.270 \\
\hline & \multicolumn{6}{|c|}{32 Non-soutbern States } \\
\hline 1910 & 0.112 & 0.043 & 0.384 & 0.111 & 0.033 & 0.297 \\
\hline 1920 & 0.223 & 0.069 & 0.309 & 0.199 & 0.056 & 0.281 \\
\hline 1928 & 0.361 & 0.093 & 0.258 & 0.321 & 0.086 & 0.268 \\
\hline 1938 & 0.581 & 0.097 & 0.167 & 0.559 & 0.075 & 0.134 \\
\hline
\end{tabular}

Notes and Sources:

State-level high-school graduation data from various sources; see Goldin (1994, 1997). Weighted data use the number of 17 -year olds in the state. The coefficient of variation is the (standard deviation/mean). 
Table 2

Comparative Education Data for Youth 14 to 18-Years Old:

Great Britain and the United States

\begin{tabular}{|c|c|c|c|c|c|c|}
\hline \multirow[b]{2}{*}{ Year } & \multicolumn{3}{|c|}{ British School Attendance Rates } & \multirow[b]{2}{*}{ Year } & \multicolumn{2}{|c|}{$\begin{array}{l}\text { U.S. High School Enrollment and } \\
\text { Gradration Rates }\end{array}$} \\
\hline & 14-year olds & 17-year olds & $\begin{array}{l}15 \text { to } 18 \text {-year } \\
\text { olds }\end{array}$ & & $\begin{array}{c}\text { Enrollment/ } 14 \text { to } \\
17 \text {-year olds }\end{array}$ & $\begin{array}{l}\text { High school } \\
\text { graduates } / 17 \text {-year olds }\end{array}$ \\
\hline 1870 & 2 & 1 & n.a. & 1870 & n.a. & 2.0 \\
\hline $1900 / 02$ & 9 & 2 & n.a. & 1900 & 10.6 & 6.4 \\
\hline $1911 / 12$ & 12 & 1 & n.a. & 1910 & 14.5 & 8.8 \\
\hline 1931 & n.a. & n.a. & $9.4-10.6$ & 1930 & 51.1 & 29.0 \\
\hline $1936 / 38$ & 38 & 4 & n.a. & 1938 & 67.7 & 45.6 \\
\hline c. 1950 & $100^{b}$ & 10.5 & $\begin{array}{c}12.6 \\
{[14.4]^{\mathrm{e}}}\end{array}$ & 1950 & 74.5 & 59.0 \\
\hline 1956 & 100 & n.a. & 14.9 & 1956 & 83.5 & 63.1 \\
\hline 1957 & 100 & 9.0 & 16.0 & & & \\
\hline $1960 / 62$ & 100 & 15 & 17.5 & 1960 & 86.9 & 69.5 \\
\hline
\end{tabular}

a The 15 to 18 year old group is defined as $[15,19)$, that is it includes those who are just 15 years old but excludes those who are just 19 years old.

b. The 100\% figure is assumed for 14-year olds because their attendance at some school was mandatory after 1944 .

c. The $14.4 \%$ figure is estimated for just males, using data for 1948 .

Sources and Notes:

The terms "attendance" and "enrollment" are taken from Ringer (1979) for England/Wales, and from the Biennial Surveys for the United States. "Attendance" for Britain means "full-time attendance in any school." But "attendance" in England/Wales often meant "on the registers," which seems more like enrollment. Attendance figures are almost always lower than enrollment data within 2 country, but for these comparisons, the differences may be slight.

England and Wales Ringer (1979) all years, except those that follow. The 15 to 18-year old group in attendance is 15 years and over divided by the 15 to 18 -year old group in England and Wales only. The 14 and-17 year old percentages are for full-time attendance at any school and refer to all of Great Britain.

1911/12. U.S. Bureau of Education, Biennial Survey of Education, 1916-18, p. 25 (the Lewis Report, 1917, is the original source of these data). Only 13\%, it was stated, engaged in full-time education beyond age 14, and $19.5 \%$ had some education between ages 14 and 18 but less than $1 \%$ were in school between ages 17 and 18. See also Matthews (1932) whose data are derived from the Lewis Report.

1931: Board of Education for England and Wales (1932) provides information on "students on the registers" by age for schools receiving public funds. These schools include primary institutions, and maintained and direct grant secondary institutions. I have estimated the number of youths 15 to 18 -years old in entirely private institutions, mainly at the secondary level. The estimating procedure uses data from university enrollments and makes assumptions regarding the proportion of private secondary students who continued to university, as well as the proportion of public school students who did (all based on evidence for 1948). A set of reasonable assumptions results in the $9.4 \%$ figure and assumptions designed to produce an upper bound result in the $10.6 \%$ figure. The figures exclude any youths 15 to 18 -years old in university.

1956: Carr-Saunders, et al. (1958), p. 60 gives the number of pupils on school registers by age and the total in the age group. The figure will not include youths at university.

1957: Dewhurst (1961). The 15 to 18-year group is obtained by a simple average of the rates for the four years.

United Stater, allyears. U.S. Department of Education (1993). Enrollments are divided by the group 14 to 17 -years old (although it is likely that the group was in the 15 to 18 -year old range). 
Table 3

Explaining Total (Public and Private) Secondary-School Graduation Rates by States

\begin{tabular}{|c|c|c|c|c|c|c|}
\hline & $\begin{array}{c}\text { (1) } \\
1910 \text { Level }\end{array}$ & $\begin{array}{c}(2) \\
\Delta(1928- \\
1910) \\
\end{array}$ & $\begin{array}{c}(3) \\
1928 \text { Lexel }\end{array}$ & $\begin{array}{c}(4) \\
1928 \text { Level }\end{array}$ & $\begin{array}{c}(5) \\
\Delta(1938- \\
1928) \\
\end{array}$ & $\begin{array}{c}(6) \\
\Delta(1938- \\
1928)\end{array}$ \\
\hline $\begin{array}{l}\text { Log per capita wealth, } 1912 \text { or } \\
1922, \times 10^{-1}\end{array}$ & $\begin{array}{c}0.236 \\
(0.0901)\end{array}$ & $\begin{array}{c}0.857 \\
(0.260)\end{array}$ & $\begin{array}{c}0.852 \\
(0.368)\end{array}$ & & $\begin{array}{l}1.25 \\
(0.345)\end{array}$ & \\
\hline$\% \geq 65$ years, 1910 or 1930 & $\begin{array}{l}2.13 \\
(0.260)\end{array}$ & $\begin{array}{l}-1.749 \\
(0.737)\end{array}$ & $\begin{array}{c}1.423 \\
(0.788)\end{array}$ & $\begin{array}{c}1.846 \\
(0.774)\end{array}$ & $\begin{array}{l}-0.527 \\
(0.866)\end{array}$ & \\
\hline $\begin{array}{l}\% \text { of labor force in } \\
\text { manufacturing, } 1910 \text { or } 1930\end{array}$ & $\begin{array}{l}-0.0673 \\
(0.0335)\end{array}$ & $\begin{array}{l}-0.0495 \\
(0.0947)\end{array}$ & $\begin{array}{l}-0.144 \\
(0.0972)\end{array}$ & $\begin{array}{c}0.989 \\
(0.481)\end{array}$ & $\begin{array}{c}0.126 \\
(0.0934)\end{array}$ & $\begin{array}{c}0.203 \\
(0.0723)\end{array}$ \\
\hline$\%$ Catholic, 1910 or 1926 & $\begin{array}{l}-0.0913 \\
(0.0305)\end{array}$ & $\begin{array}{l}-0.265 \\
(0.0900)\end{array}$ & $\begin{array}{l}-0.377 \\
(0.0867)\end{array}$ & $\begin{array}{l}-0.274 \\
(0.0849)\end{array}$ & $\begin{array}{c}0.0595 \\
(0.0841)\end{array}$ & \\
\hline South & $\begin{array}{l}-0.0449 \\
(0.00932)\end{array}$ & $\begin{array}{l}-0.0735 \\
(0.0267)\end{array}$ & $\begin{array}{l}-0.0935 \\
(0.0272)\end{array}$ & $\begin{array}{l}-0.131 \\
(0.294)\end{array}$ & $\begin{array}{c}0.0375 \\
(0.0306)\end{array}$ & \\
\hline New England & $\begin{array}{c}0.0444 \\
(0.0121)\end{array}$ & $\begin{array}{c}0.0811 \\
(0.0333)\end{array}$ & $\begin{array}{l}0.100 \\
(0.0310)\end{array}$ & & & \\
\hline Middle Atlantic & & & & $\begin{array}{l}-0.0635 \\
(0.0338)\end{array}$ & $\begin{array}{c}0.0620 \\
(0.0188)\end{array}$ & \\
\hline $\begin{array}{l}\text { Males in public colleges } / 17 \text {-year } \\
\text { olds, } 1910\end{array}$ & & $\begin{array}{l}1.09 \\
(0.384)\end{array}$ & & & & \\
\hline $\begin{array}{l}\text { Wage in manufacturing, } 1929, \times \\
10^{-1}\end{array}$ & & & & $\begin{array}{c}0.241 \\
(0.0974)\end{array}$ & & \\
\hline $\begin{array}{l}\text { Wage } \times \% \text { in manufacturing, } \times \\
10^{-1}\end{array}$ & & & & $\begin{array}{l}-0.827 \\
(0.375)\end{array}$ & & \\
\hline $\begin{array}{l}\text { Auto registrations per capita, } \\
1930, \times 10\end{array}$ & & & $\begin{array}{c}0.0568 \\
(0.0230)\end{array}$ & $\begin{array}{c}0.0449 \\
(0.0218)\end{array}$ & & \\
\hline $\begin{array}{l}\text { Log agricultural income per } \\
\text { agricultural worker, } 1920\end{array}$ & & & & & & $\begin{array}{r}0.0985 \\
(0.0174)\end{array}$ \\
\hline $\begin{array}{l}\text { Change } \% \text { unemployment, } 1930 \\
\text { to } 1940, \times 10^{-2}\end{array}$ & & & & & & $\begin{array}{c}0.900 \\
(0.306)\end{array}$ \\
\hline Constant & $\begin{array}{l}-0.136 \\
(0.0709)\end{array}$ & $\begin{array}{l}-0.324 \\
(0.199)\end{array}$ & $\begin{array}{l}-0.468 \\
(0.273)\end{array}$ & $\begin{array}{l}-0.0962 \\
(0.115)\end{array}$ & $\begin{array}{l}-0.814 \\
(0.276)\end{array}$ & $\begin{array}{l}-0.541 \\
(0.104)\end{array}$ \\
\hline $\mathrm{R}^{2}$ & 0.895 & 0.758 & 0.874 & 0.864 & 0.679 & 0.708 \\
\hline Root MSE & 0.172 & 0.0474 & 0.0451 & 0.0476 & 0.0400 & 0.0368 \\
\hline $\begin{array}{l}\text { Mean (unweighted) of } \\
\text { dependent variable }\end{array}$ & 0.0882 & 0.212 & 0.291 & 0.291 & 0.204 & 0.204 \\
\hline
\end{tabular}


<smiles>C=C</smiles> 
Table 4

Explaining School Attendance of 15, 16 and 17-Year Olds, by City: 1910, 1920, 1930

\begin{tabular}{|c|c|c|c|c|c|c|}
\hline & \multicolumn{2}{|c|}{$\begin{array}{c}1910 \\
(15 \text { to } 17 \text {-year olds })\end{array}$} & \multicolumn{2}{|c|}{$\begin{array}{c}1920 \\
\text { (16 to } 17 \text {-year olds) } \\
\end{array}$} & \multicolumn{2}{|c|}{$\begin{array}{c}1930 \\
(16 \text { to } 17 \text {-year olds })\end{array}$} \\
\hline & $\hat{\beta}$ & s.e. & $\hat{\hat{\beta}}$ & s.e. & $\hat{\boldsymbol{\beta}}$ & s.e. \\
\hline$\%$ production workers, in year & -0.687 & 0.0823 & -0.300 & 0.0721 & -0.375 & 0.107 \\
\hline$\%$ child in mfg., 1910 or 1920 & -2.28 & 0.301 & -0.679 & 0.312 & -1.052 & 0.465 \\
\hline Log city population in year $\times 10^{-1}$ & -0.170 & 0.0550 & -0.0610 & 0.0671 & 0.121 & 0.0902 \\
\hline$\%$ foreign born in year & -0.169 & 0.0622 & -0.0755 & 0.0860 & 0.202 & 0.113 \\
\hline$\%$ non-white in year & -0.303 & 0.177 & -0.449 & 0.181 & -0.895 & 0.171 \\
\hline$\%$ Catholic, 1926 & & & -0.0945 & 0.0438 & -0.133 & 0.0528 \\
\hline Log per capita wealth, 1925 or 1930 & & & 0.0578 & 0.0169 & 0.0803 & 0.0233 \\
\hline Population density in year $\times 10^{-2}$ & & & -0.237 & 0.0925 & -0.628 & 0.139 \\
\hline School density, 1923 or 1933 & & & 78.2 & 33.1 & 144.4 & 43.9 \\
\hline Vocational school density, 1933 & & & & & 185.6 & 90.9 \\
\hline$\%$ managers in mfg., 1920 & & & 0.727 & 0.146 & & \\
\hline$\%$ textiles \& clothing in mfg., 1920 & & & -0.135 & 0.0545 & & \\
\hline$\%$ chemicals in mfg., 1920 & & & -0.779 & 0.404 & & \\
\hline$\%$ white collar in labor force, 1930 & & & & & 0.800 & 0.185 \\
\hline$\%$ bldg. trades in labor force, 1930 & & & & & -0.682 & 0.358 \\
\hline New England & -0.0238 & 0.0256 & -0.0921 & 0.0241 & -0.209 & 0.0302 \\
\hline Middle Atlantic & -0.109 & 0.0224 & -0.153 & 0.0221 & -0.188 & 0.0272 \\
\hline East North Central & -0.115 & 0.0226 & -0.140 & 0.0202 & -0.0834 & 0.0257 \\
\hline West North Central & -0.0941 & 0.0240 & -0.124 & 0.0231 & -0.175 & 0.0300 \\
\hline Mountain & -0.0249 & 0.0326 & 0.00845 & 0.0332 & -0.0874 & 0.0450 \\
\hline Constant & 0.904 & 0.0630 & 0.242 & 0.130 & 0.106 & 0.173 \\
\hline $\mathrm{R}^{2}$ & 0.673 & & 0.695 & & 0.669 & \\
\hline Root MSE & 0.0648 & & 0.0688 & & 0.0864 & \\
\hline Mean of dependent variables & 0.443 & & 0.405 & & 0.628 & \\
\hline Number of Observations & 182 & & 212 & & 209 & \\
\hline
\end{tabular}

Notes:

Standard errors (s.e.) are next to the coefficients. Ordinary least squares estimation used with no weighting. Weighting by population does not affect results. Cities include only those with more than 10,000 persons in 1910 outside the South. The few cities that merged with another or divided into two were kept as one unit, either merged or separated, throughout the sample period. 
Sources:

Dependent variable:

Percentage of 16 and 17 -year olds who attended any school during some time in the year preceding the census: U.S. Bureau of the Census $(1912,1923,1932)$.

Independent variables. All variables are from the U.S. Bureau of the Census, censuses of population or manufactures for the relevant years, except where noted. Unless specified as the census of manufactures, the source is the population census in the relevant year. Population census documents are U.S. Bureau of the Census $(1912,1923$, 1932); census of manufactures documents are U.S. Bureau of the Census $(1913,1923 a, 1933)$.

$\%$ production workers, in year. production workers in manufacturing as a percentage of the city population. Production worker data are from the census of manufactures.

$\%$ cbild in mfg., 1910 or 1920: child workers in manufacturing as a percentage of all production workers in manufacturing in the city. The 1910 and 1920 estimations use 1910; the 1930 estimation uses 1920 . Production worker and child worker data are from the census of manufactures for 1909, and 1919.

Log city pop. in year. log of the city population in either 1910, 1920, or 1930.

$\%$ foreign born in year. percentage of city population that is foreign bom in 1910, 1920, or 1930.

$\%$ non-white in year. percentage of the city population that is non-white in 1910,1920, or 1930.

$\%$ Catbolic in year. percentage of the city population (average of 1920 and 1930) who are members of the Roman Catholic church in 1926. U.S. Department of Commerce (1930).

Log wealth, 1925 or 1930: $\log$ of the estimated true value of the per capita wealth of the city. U.S. Bureau of the Census $(1927,1932 a)$.

Population density in year. population in year/area of city. Area data are mainly from U.S. Bureau of the Census (1932a).

School density. number of secondary schools in 1923 or 1933/area of the city in 1925 or 1930 . Number of secondary schools $=$ number of high schools $+(0.3) \cdot$ number of junior high schools. U.S. Bureau of Education, Biennial Sumeys (various years).

Vocational school density: number of vocational high schools in 1933/area of the city in 1930. U.S. Bureau of Education, Biennial Surveys (various years).

$\%$ managers in manufacturing: percentage of all manufacturing workers who are managers; obtained from Robert Whaples.

$\%$ textiles of clothing in mfg: percentage of all manufacturing workers employed in the textiles and clothing industries; obtained from Robert Whaples.

$\%$ chemical in mfg: percentage of all manufacturing workers employed in the chemicals industry (note: chemical includes fertilizers); obtained from Robert Whaples.

$\%$ white collar in labor force: professional, clerical, trade, public service workers/all in labor force in city.

$\%$ bldg. trades in labor force. workers in the building trades/all in labor force in city. 